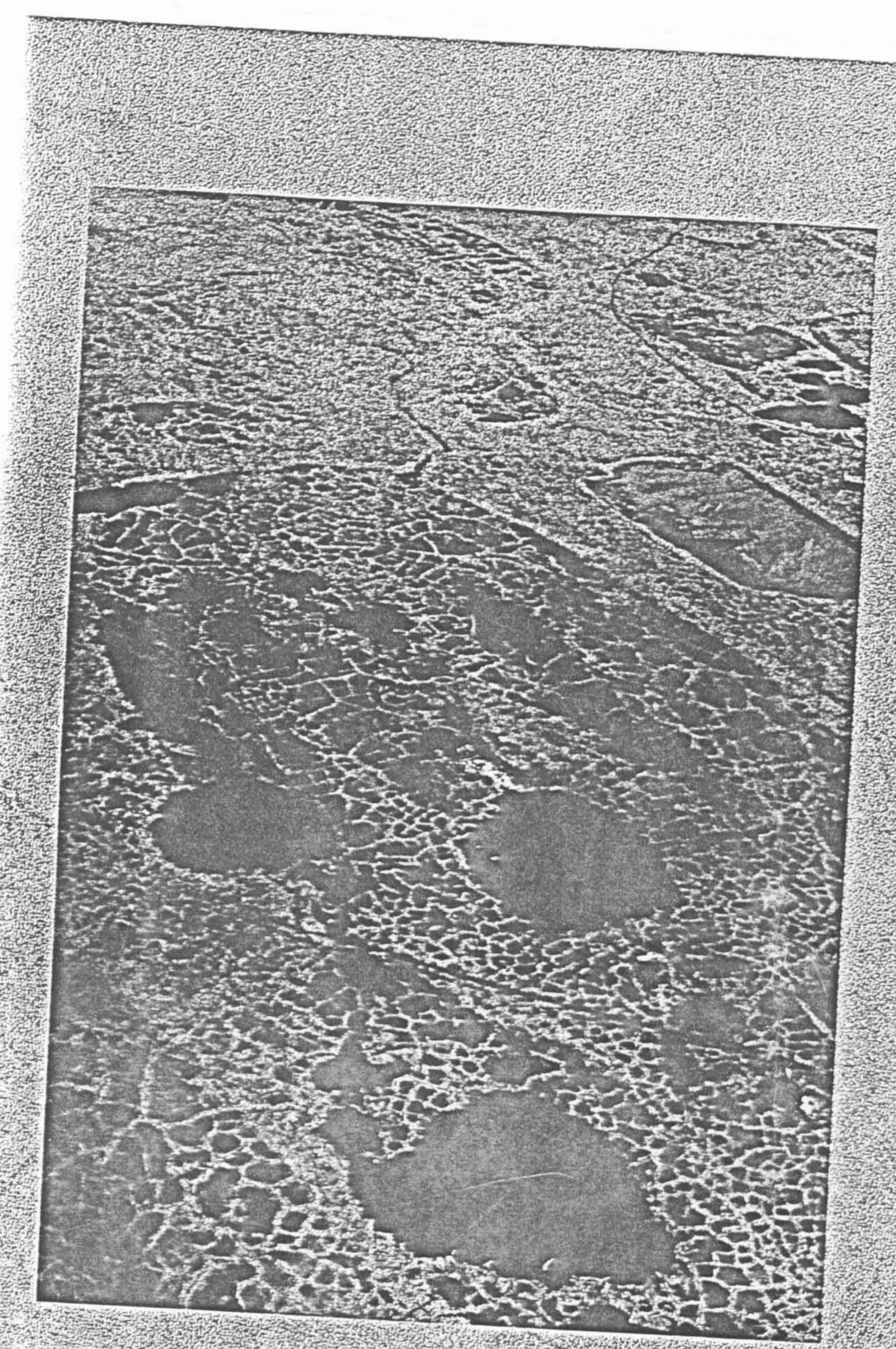

\title{
SURFICIRL GEOLOGY AND PROCESSES, PRUDHOE BAY OIL FIELD, ALASKA, WITH HYDROLOGIC IMPLICATIONS
}

fandall G. Updike and Mark D. Howlond

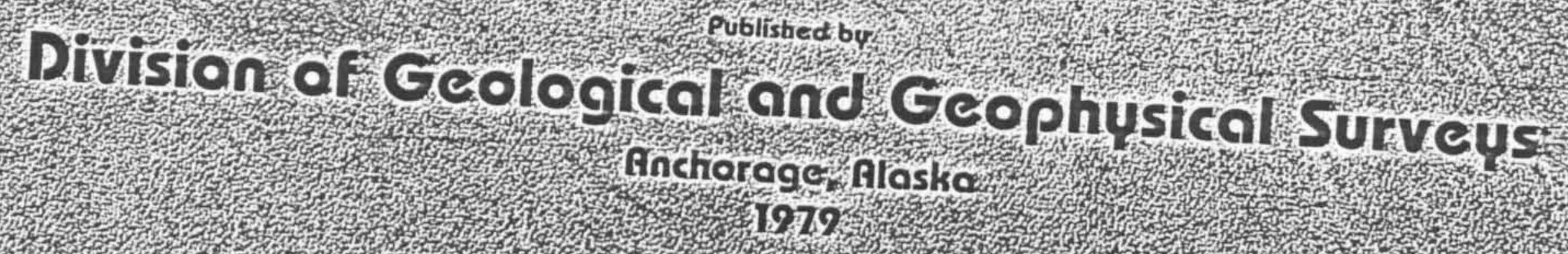




\section{SURFICIAL GEOLOGY AND PROCESSES PRUDHOE BAY OIL FIELD, ALASKA, WITH HYDROLOGIC IMPLICATIONS}

By

Randall G. Updike and Mark D. Howland

SPECIAL REPORT 16

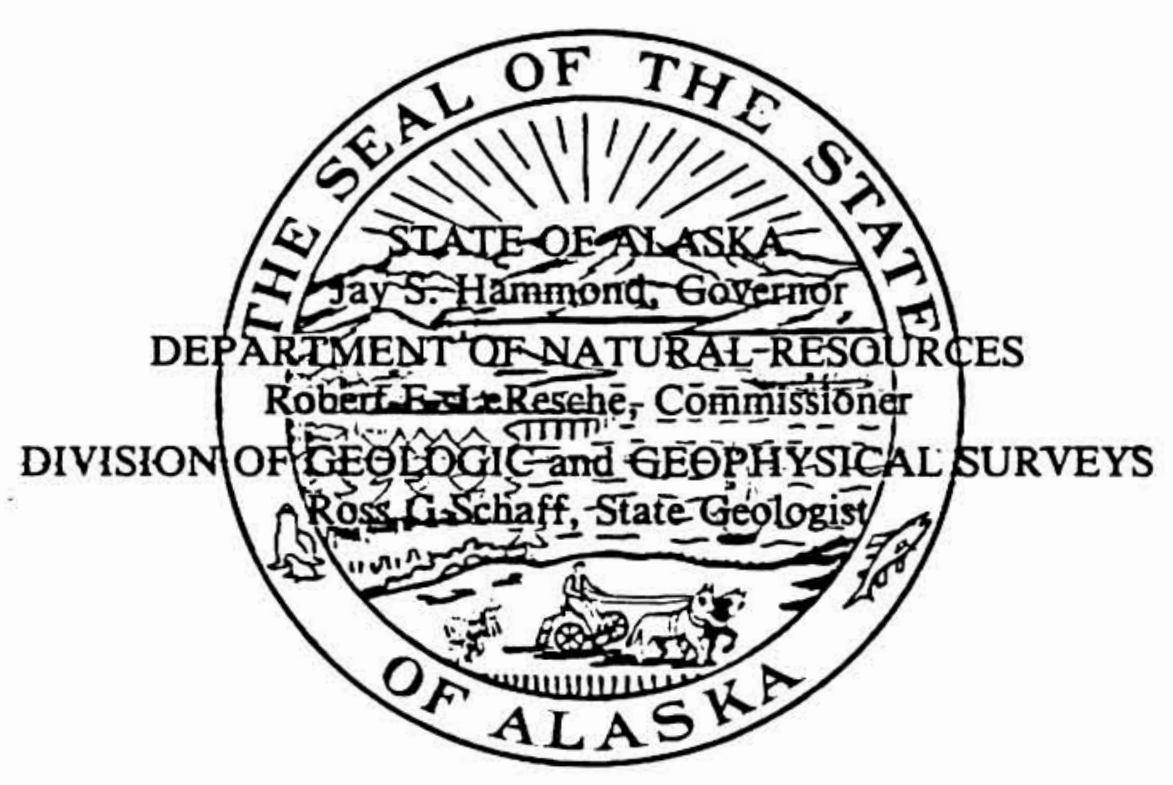

Published by
DIVISION OF GEOLOGICAL and GEOPHYSICAL SURVEYS Anchorage, Alaska

1979 
CONTENTS

Purpose of the Report Acknowledgements

Physical Setting

Vegetation

Techniques of Investigation

Geologic Setting

Map Unit Parameters

Description of Surficial Geologic Units

Upland tundra deposits (ut)

Fluvial deposits

Active floodplain sands and gravels (af)

Inactive floodplain sands and gravels (if)

Lower fluvial terrace deposits, ice-wedge polygons (It)

Lower fluvial terrace deposits, Dartially scoured (Its)

Upper fluvial terrace deposits (ot)

Thermokarst stream channel deposits (ts)

Thermokarst stream terrace deposits (tt)

Lacustrine deposits

Deposits associated with large area lakes (IdI), intermediate

Deposits associated with partially drained lake basins (Idp)

Deposits associated with partially drained late

Deposits associated with drained lakes (Idd)

Deposits associated with abandoned lacustrine strandlines (Ida)

Deposits of marine shorelines (cd) ... .

Sands and silts of river deltas (ad and id)

Eolian deposits

Active eolian silt and sand dunes (an)

Inactive eolian silt and sand dunes (ia)

and sitt associated with deflation basins (db)

Hydrology

General statement

Lakes. .

Ground water

Conclusions

Explanation of Derivative Maps, Plates 13 and 14

Man-induced Environmental Hazards

References Cited . . .

\section{ILLUSTRATIONS}

Figure 1.

Figure 2.

Figure 3.

Figure 4.

Figure 5

Figure 6.

Figure 7

Figure 8

Figure 9.

Figure 10

Plate 1.

Plates 2-12

Plate 13.

Plate 14

Plate 15.

Plate 16.

Plate 17. Legend for surficial geologic maps, Plates 2-12.

Surficial geologic maps of the Prudhoe Bay Oil Field.

Derivative map of the Sagavanirktok River area.

Derivative map of the Kuparuk-Putuligayuk Rivers area.
Downstream view along the west bank of the Sagavanirktok River about $150 \mathrm{~m}$ northeast Page Oblique view of the surface of a sandy gravel bar, active floodplain, Kuparuk River $\ldots \ldots \ldots \ldots, 1$ A view of partially drained lacustrine deposits as seen from the crest of a pingo $\ldots \ldots \ldots . . \ldots$ Close-up of the surface of a recently drained lake basin $\ldots \ldots \ldots \ldots \ldots \ldots \ldots \ldots$ Incomplete ice-wedge polygons associated with abandoned lacustrine strandlines $\ldots \ldots \ldots \ldots$ Aerial view of coast at Prudhoe Bay, looking west toward the Putuligayuk River $\ldots \ldots \ldots 3$ Active eolian deposits located west of the Sagavanirktok River delta $\ldots \ldots \ldots \ldots \ldots 4$ The remnant of an eolian dune now partially removed by deflation $\ldots \ldots \ldots \ldots \ldots 4$ Aerial view of BP-Sohio water reservoirs in the east channel of the Kuparuk River active floodplain 5 Abandoned road near Deadhorse rendered unusable due to thermokarst subsidence $\ldots \ldots \ldots$. 5

Composition and transient conditions of surficial geologic units mapped on Plates 2 through 12.

Composition and transient conditions of surficial geologic units (continuation of Plate 15).

Histograms showing relative particle size distribution of sediment samples representative of surficial geologic map units.

NOTE: In this report most dato are presented exclusively in the metric system. For the

\begin{tabular}{|l|l|l|}
\hline \multicolumn{1}{|c|}{ MULTIPLY } & BY & TO OBTAIN \\
\hline centimeters $(\mathrm{cm})$ & $0.393 \%$ & inches \\
meters $(\mathrm{m})$ & 3.281 & feet \\
meters $(\mathrm{m})$ & 1.094 & yards \\
kilometers $(\mathrm{km})$ & 0.6214 & miles \\
square centimeters $\left(\mathrm{cm}^{2}\right)$ & 0.1550 & square inches \\
square kilometers $\left(\mathrm{km}^{2}\right)$ & 0.3861 & square miles \\
cubic centimeters $\left(\mathrm{cm}^{3}\right)$ & 0.0610 & cubic inches \\
cubic meters $\left(\mathrm{m}^{3}\right)$ & 1.308 & cubic yards \\
liters $(\mathrm{l})$ & 0.2641 & USA gallons \\
grams $(\mathrm{gm})$ & 0.0353 & ounces \\
kilograms $(\mathrm{kg})$ & 2.205 & pounds \\
meters per kilometer $(\mathrm{m} / \mathrm{km})$ & 5.28 & feet per mile \\
\hline
\end{tabular}

Cover Photograph: Aerial view of Arctic Coastal Plain near Prudhoe Bay. Several drained and partially drained lake 


\section{SURFICIAL GEOLOGY AND PROCESSES \\ PRUDHOE BAY OIL FIELD, ALASKA, WITH HYDROLOGIC IMPLICATIONS}

Randall G. Updike and Mark D. Howlan

PURPOSE OF THE REPORT

The Prudhoe Bay Oil Field is a unique experimental model of industrialization and dent tabitation in one of the most difficult environments of North America. The intent of this report is to (a) presente information on the surficial geology of the field that may be used as base-line information for future development, (b) locate areas of potential aggregate resources for facility and roadway construction, and (c) evaluate potential water resources that have become critical due to increased demand

ACKNOWLEDGMENTS

The authors wish to thank the following individuals and organizations for providing information and data for this report: Sy Price, Alaska State Pipeline Coordinators Office; Don Keyes, U. S. Bureau of Land Management Alaskan Pipeline Office; Charles Sloan and Gordon Nelson, U. S. Geologital Survey (USGS); Brent Petrie, Alaska Department of Natural Resources; Jerry Arnold and Pat Metz, Atlantic Richfield Oil Company (ARCO); Tom Olson, Air Photo Tech; Meg Hayes, Alaska Division of Lands; lim Kross and Dennis Ward, Environment Sevices, td.

Particular appreciation is expressed to Church Campbell, Prudhoe Field Manager, ARCO, and Slim Gilchrist, Prudhoe Field Manager, BP, who greatly assisted in field access and logistics. Base maps and aerial photography werc provided by Air Photo Tech, Anchorage, by permission of BP. The personnel of the Alaska State Division of

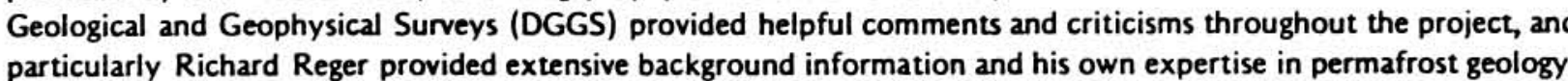
PHYSICAL SETTING

In the ten years that have passed since the success of Atlantic Richfield's discovery well, over 150 additional wells have been drilled in the Prudhoe Bay Oil Field. The majority of these wells are located on the Arctic Coasta Pain, within 15 to $20 \mathrm{~km}$ of the Best by sea This fild of approx of the the Kuparuk Riveration and supportive service facilitios.

The severe climate is a dominant factor of the ecosystem in which the Prudhoe field is located. This is, of course, due to its far northern location: $147^{\circ} 48^{\prime}$ to $149^{\circ} 5^{\prime}$ west longitude, $70^{\circ} 10^{\prime}$ to $70^{\circ} 25^{\prime}$ north latitude. Although continuous climatological data are lacking for Prudhoe Bay, conditions are similar to Barrow where dat are recorded: mean annual maximum daily temperature $=-9^{\circ} \mathrm{C}\left(16^{\circ} \mathrm{F}\right.$ ), mean annual minimum daily temperature $15.5^{\circ} \mathrm{C}\left(4^{\circ} \mathrm{F}\right.$ ), 320 days per year with temperatures below $0^{\circ} \mathrm{C}, 10 \mathrm{~cm}$ (4.1 inches) of precipitation per year, $65 \mathrm{~cm}$
$(27$ inches) of snowfall per year (U. S. Department of Commerce, 1961).

\section{VEGETATION}

A brief description of the plant communities occurring in this part of the Arctic Coastal Plain is included because (a) variations of vegetation are often visible on aerial photographs and are valuable indicators of slope, drainage, and permafros

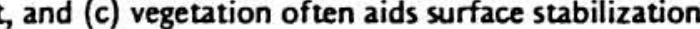

Five major plant communities are recognized in the Prudhoe Bay area: (1) freshwater vegetation, (2) aquatic heath tundra, and (5) dwarf shrub-heath tundra (Churchill, 1955; Britten, 1957; Drew and others, 1958; Spetzman, 959; Wiggins and Thomas, 1962; and Hussey and Anderson, 1963).

The freshwater aquatic vegetation inhabits both lakes and thermokarst streams. In lakes, the vegetation often forms concentric zones parallel to the shoreline, reflecting water depths in the lake. Most plants inhabit water less pondweed (Potamogeton), (b) rooted emergents occurring in water 0.3 to $1.0 \mathrm{~m}$, including pondgrass (Arctophily horsetail (Equisetum), mares tail (Hippuris), and cinquefoil (Potentilla), and (c) transitionally emerged plants occurring in water less than 0.2 to $0.3 \mathrm{~m}$ deep, including sedge (Carex aquatilis), cottongrass (Eriophorum angustiofolum), and mountain foxtail (Alopecurus alpinus). Also seeking wet environments is the aquatic waterways community, found along large streams, rivers, and in protected areas along the coast. Several species of dwarf willow
(Salix), vetches (Astraguluss), saxifrages (Saxifragas), and louseworts (Pedicularis) are found, with Saxifraga becoming minant over $\underline{S a l i x}$ in more saline coastal waters.

The wet sedge meadows are broad, flat areas which are poorly drained The low-center ice-wede polygons which enclose marshes are the most typical environment Sedge (Carex), cottongrass (Eriophorum), sphagnum moss Sphagnum), and arctic grass (Dupontia) are most common.
Grasses dominate in the tussock-dwarf heath community which is on poorly to moderately drained soils typically covered by standing surface water during spring melt. Chief among these are several species of Eriophorum as well as Dryas integrifolia (mountain vens), Betula nana (dwarf birch), and Arctagrostis latifolia (polar grasss). 列 on pingos, stream banks, or on well-drained gravel substrates such as wind-scoured river terraces. Numerous species ding Poa rectica (arctic bluegrasss), Salix reticulata, Dryas integrifolia, Eriphorum

\section{TECHNIQUES OF INVESTIGATION} Prior to initiation of mapping and field evaluation, the authors reviewed an extensive published literature
pertaining to Prudhoe Bay and other areas of the Arctic Coastal Plain. In addition, unpublished data and reports pertaining to Prudhoe Bay and other areas of the Arctic Caastal Plain. In addition, unpublished data and reports
were provided by the oil producers, and by state and federal agencies. In conjunction with the literature review, communication was established and maintained with agencies and companies having interests in the Prudhoe Bay
Field. All petroleum companies with leases in the Prudhoe Bay area were contacted. BP.Sohio and ARCO are the
primary operators in the field and provided perspectives on present operations, problems they have encountered, and primary operators in the field and provide

projected expansion needs they foresee.
The surficial geologic mapping utilized aerial photography, topographic base maps, and field study. Aerial photographs at three scales were used: black-and-white 1:24,000 photography (Air Photo Tech, 1973), U-2 wily 1973). The high-altitude U-2 and ERTS photography were primarily used in evaluating lake conditions during depths of lakes on the Arctic Coasters (1975) demonstrated that ERTS imagery can be used to establish relative deptography also the Arctic Coastal Plain. This technique was effectively utilized in this project. The U-2 low-level black-and-white photography.

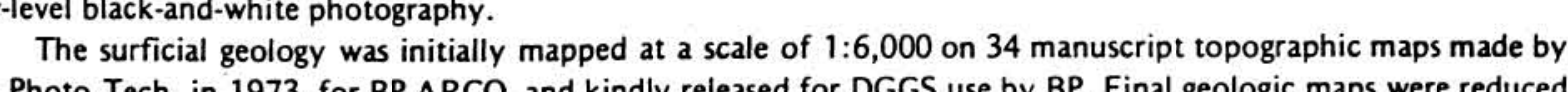
Air Photo Tech, in 1973, for BP.ARCO, and kindly released for DGGS use by BP. Final geologic maps were reduce B-3, and B-4 (1:63,360 series) and Bechey Point A-2NW, A-3NE, A-3NW, A-ANE, B-2SW, B-3SE, B-3SW, B-3NW, $B-4 S E$, and $B-4 N E(1: 24,000$ Orthophoto series). Field work was facilitated by the network of gravel roads traversing the field. Remote areas were reached by foot or helicopter. ARCO and $B P$ allowed free access to all areas of the field.
CEOLOGIC SETTING

The study area lies entirely within the Arctic Coastal Plain physiographic province. Although Tertiary edimentary rocks are exposed along the Sagavanirktok River to the south, no bedrock crops out in the study area. The Gubik Formation of Pleistocene age (Black, 1964) completely blankets Tertiary and Cretaceous bedrock, often to thicknesses greater than $500 \mathrm{~m}$. The formation consists of coastal marine sands and gravels interbedded with fluvial channel and deltaic sediments. Much of the Gubik Formation is overlain by sil deposis less than $5 \mathrm{~m}$ thick,

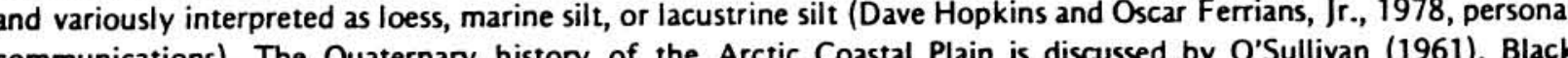
communications). The Quaternary history of the Arctic Coast
(1964), Hopkins (1967), and Sellman, Brown, and others (1975).

The single most important factor governing the geomorphic processes which affect the Quaternary sediments is the severe temperature regime of the arctic environment. This results in continuous permafrost conditions to depths greater than $650 \mathrm{~m}$ (Stoneley, 1970). This permanently frozen condition has been maintained since the Pleistocene Epoch (Péwé, 1975). Usually, only the upper 1 to $3 \mathrm{~m}$ of ground is thawed, either seasonally (active layer) or adjacent to bodies of surface water. Ice within the permafrost may take several forms, most commonly as ice

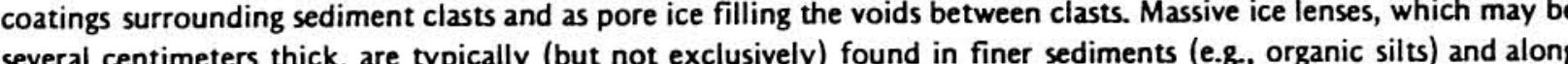
minor unconformities. All of these varieties of ground ice are found in both the permafrost and seasonally frozen ground. Intense chilling of near-surface permafrost of ten causes contraction and cracking of the ice-bonded sedimen in polygonal patterns. These open fractures subsequently are filled with foliated ice to form ice-wedge polygons (Lachenbruch, 1962). Processes such as strong, unidirectional east-northeast winds, stream erosion and deposition, lacustrine and coastal erosion and deposition, and mass movement alter the surface of the perennially frozen

\section{MAP UNIT PARAMETERS}

Four parameters considered in establishing and mapping the surficial geologic units are: type of landform, relative age, composition, and transient conditions. During the mapping process, landforms (e.g. eolian dunes, river terraces, lake basins) were first recognized and relative ages were determined where possible (e.g., stabilized dunes older than active dunes). Relative age determinations were based upon the preservation of the primary landform, devenppment of ice-wedge polygons. Composition, including sediment size range, variation with depth, and ice conditions (foliated ice wedge polygons, pore ice, ice lenses), was determined by field examination, communicatio with field operators, and on-file subsurface data. Transient conditions include responses of the mapped unit to seasonal fluctuations of surface conditions such as spring flooding of rivers, thawing of the active layer, deflation, tundra-polygon flooding, surface drainage characteristics, and thermokarst erosion. Transient conditions are mos significant in environmental and engineering considerations. The parameters of physiography (process and landform)
and restative ages are discussed in the text below. Composition and transient conditions are present in table form (pls 15-16). Representative size-distribution histograms for the sediment types are given on plate 17. DESCRIPTION OF SURFICIAL GEOLOGIC UNITS Upland tundra deposits (ut)

As previously noted the entire mapped area is underlain by at least $500 \mathrm{~m}$ of unconsolidated stratified sith, sand, and gravel, and generally is covered by 1 to $3 \mathrm{~m}$ of silt. Except for the upper 1 to 2 meters, this sediment is erosion, areas are herein referred to as upland tundra deposits. The upland tundra unit (ut) is distinguished as being the oldest map unit All other units either overlie it, or
cut across it, and there is no indication of fluvial or lacustrine modification (fig. 1). The unit is related to the origina Quaternary marine coastal plain sedimentation, forming an unbounded upland surface with an average slope of
about 2 to $4 \mathrm{~m} / \mathrm{km}$ toward the north or northeast.

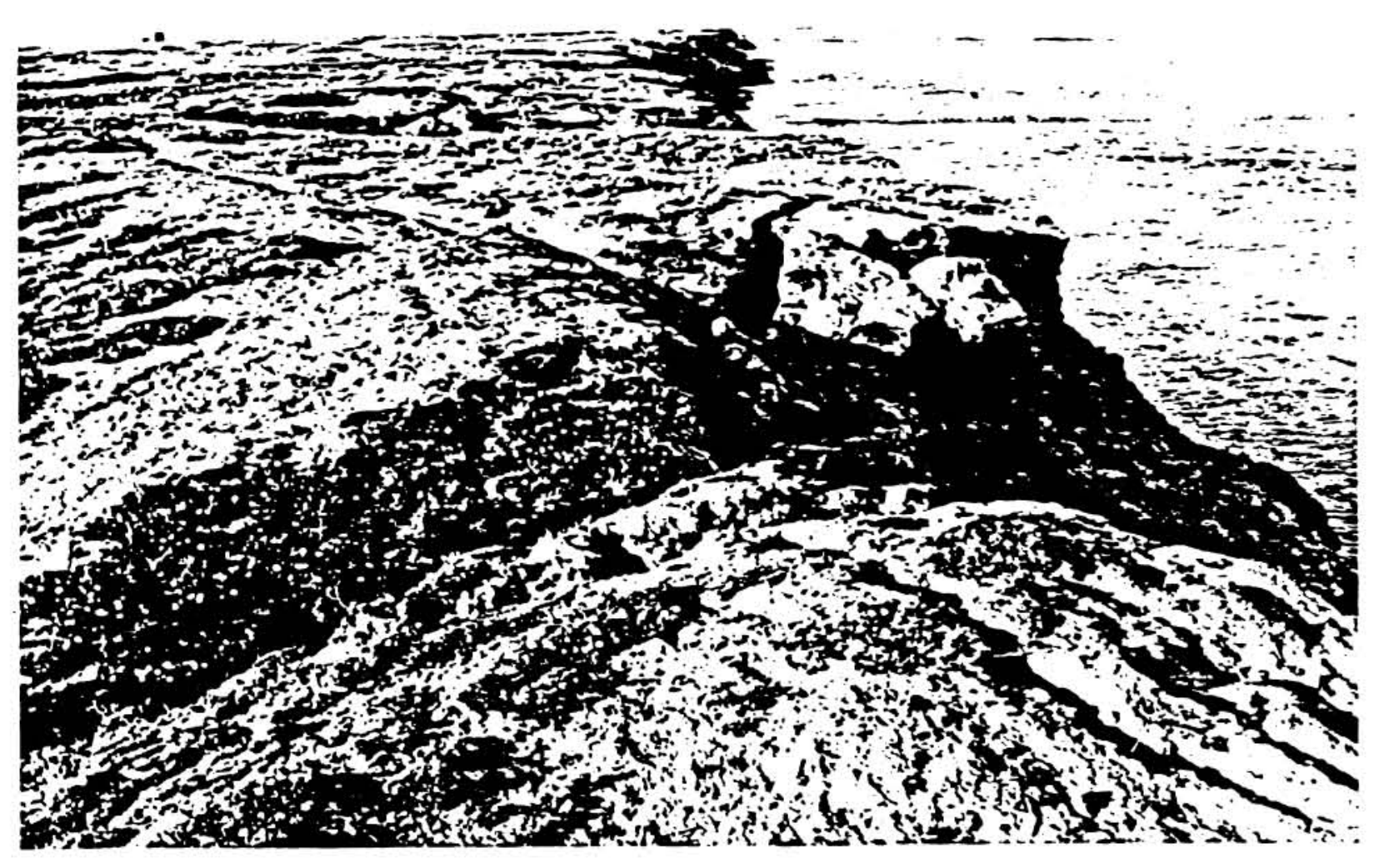

Figure 1. Downstream view along the west bank of the Sagavanirktok River, about $150 \mathrm{~m}$ northeast of the Webster Lake Reservoir, showing active thermokarst erosion along ice-wedge polygons (plage 6). Scarp separating the upland tundra surface (ut) from the active floodplain (af) is approximately $7 \mathrm{~m}$ high.

During summer months the upper 1 to $2 \mathrm{~m}$ of the upland tundra deposits thaw. It is within this active layer that the arctic tundra plant community thrives, establishing a thick, continuous organic mat. The sitt blanket and 
thawed, and conducting heat from the ground in winter. Thus, although perennially frozen, the temperature of the upper permafrost zone fluctuates seasonally. During winter the extreme heat loss from the upper permafrost causesit to contract, resulting in polygonal cracking of the ground from below the permafrost table to the surface. Summer meltwater and water vapour can enter these cracks and freeze. Over a period of several years large masses of foliated ged due to the added increment of ground ice, the expanding sediment is forced to rise vertically adjacent to the ice wedges, resulting in double raised ridges which outline the ice-wedge polygons. In several localities (e.g., west of BP Operations Center) these low-center polygons are currently subdividing into smaller polygons. Thus, the presence of well-developed active ice-wedge polygons throughout the upland tundra unit suggests a dynamic equilibrium between the permafrost and both summer and winter atmospheric conditions. The degree of development of polygons appear to be time related, becoming more pronounced in micro-relief and more extensively subdivided
with increasing time. The low centers bounded by uplifted tundra ridges can often trap water produced either by with increasing time. The low centers bounded by upinted indra ridges can often trap water produced either by summer inhibits the tundra vegetation, accelerates summer heat flow, and eventually may initiate the thaw lake cycle.

\section{Fluvial deposits}

Two types of streams traverse the mapped area: those with waters originating from the south, outside the mapped area, and local streams derived from surface runoff and dewatering of the active layer. Three streams fall into the first category: Sagavanirktok River, Putuligayuk River, and Kuparuk River. The second category comprises numerous, unnamed streams, controlled in part by local thaw of the underlying permafrost, and which are herein
referred to as thermokarst streams. Deposits associated with these two stream types are quite different and are referred to as thern
discussed separately.

ACTIVE FLOODPLAIN SANDS AND GRAVELS (af)

Within the present-day floodplains of the Sagavanirktok, Kuparuk, and Putuligayuk Rivers are areas which are at least periodically flooded and may be submerged throughout much of the year. These areas consist predominantly of sand and gravel with minor amounts of silt (fig. 2). The deposis are in cons. occur during late spring to early summer floods, but channels remain stationary throughout the reduced flow regime of summer. The sands and gravels are primarily in-transport bedload from source areas to the south (Arctic Foothills-Brooks Range). Some gravel is yielded from thaw and mobilization of older local units but due to the low rates of lateral planation and downcutting this source in minimal. All three rivers have low-energy regimes excep during early

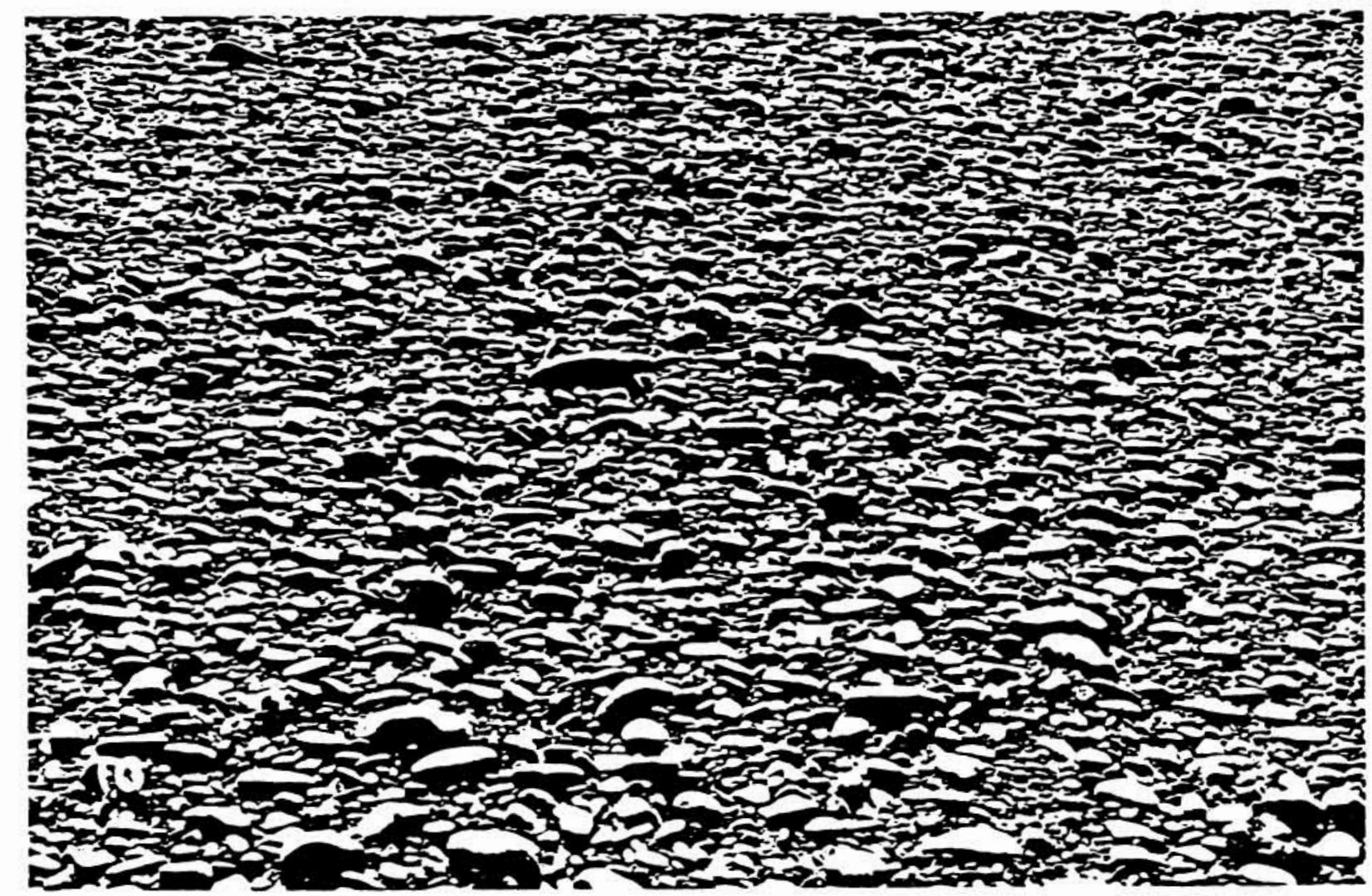

Figure 2. Oblique view of the surface of sandy gravel bar associated with the active floodplain (af), Kuparuk River. Pocket watch for scale is at lower left Upstream is at the top of the picture. Note the long-axis

INACTIVE FLOODPLAIN SANDS AND GRAVELS (if)

Both the Sagavanirktok and Kuparuk Rivers have broad floodplains with braided drainage. Parts of the floodplains have been abandoned for perhaps several years even though they are at or near the elevation of active that a thin (less than $1 \mathrm{~m}$ thick) silt cover and open grass vegetation are typically present.

The Putuligayuk River has a meandering channel morphology with abandoned meander loops and meander scars at or near present channel elevation and gradient. These channel deposits have compositional characteristic similar to inactive floodplain deposits of the Sagavanirktok and Kuparuk Rivers.

LOWER FLUVIAL TERRACE DEPOSITS, ICE-WEDGE POLYGONS (Itp)

Both the Sagavanirktok and Kuparuk Rivers have a low fluvial terrace which is 2 to $3 \mathrm{~m}$ above the active floodplain. Remnants of these terraces project above the present deltas. The terrace is bounded below by well-defined scarps descending to the present floodplain and above by scarps 2 to $5 \mathrm{~m}$ high, ascending to oider units.

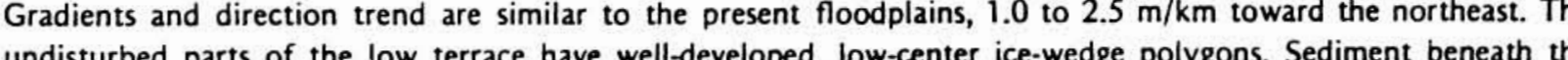
silt-tundra overburden is identical to that of the active floodplain.

LOWER FLUVIAL TERRACE DEPOSITS, PARTIALLY SCOURED (Its)

Parts of the lower terraces associated with the Sagavanirktok and Kuparuk Rivers lack visible ice-wedge polygon development. The Putuligayuk River also has a low fluvial terrace upon which ice-wedge polygons are poorly defined or absent. In all three instances the silt cover, although continuous, is thin +1.0 to $1.5 \mathrm{~m}$ thick). Old braided channel or meander scars are still visible on the terrace surface, often made noticeable by subtle changes in vegetation and surface moisture. In some instances these old channels remain as sloughs or meander scar ponds, and
in the lower reaches of the Sagavanirktok drainage system, some deep lakes occupy old braided drainage channels in the lower reaches of the Sagavanirktok drainage system, some deep lakes occupy old braided drainage channels
(pl. 13).
The three prime differences between the two low terrace map units are (a) thickness of silt cover, (b) development of ice-wedge polygons, and (c) preservation of channel scour marks. Aithough the partially-scoured weraces are typically slighty lower in telee than the polygona low terace, the two units often grade into each other (icings) which thaw in summer. This rare flooding remeves part of the sitt cover and, due to the presence of surface meltwater, adds unsual heat to the permafrost. Both effects impede ice-wedge formation and induce ground ice melting. Aufeis build-up permits the rise of water above the floodplain and promotes erosion in the flooded area melting. Aufeis build-up permits the rise of water above the floodplain and promotes erosion in the flooded area
Sands and gravels of a recent flood were found deposited on the edge of the low terrace surface along the lower
Kuparuk River, indicating that spring flood waters reach the elevation of the lower terrace tread.

UPPER FLUVIAL TERRACE DEPOSITS (ot)

Along the Sagavanirktok River a second, higher fluvial terrace is present. In the southern part of the mapped area the extent and slope of the terrace approximately parallel the existing floodplain (pl. 12); however, downstream the terrace diverges toward the northeast. The point of inflection occurs directly east of Lake Colleen. The earlier
drainage which deposited the sediment of this high terrace reached the ocean midway between the present east and drainage which deposited the sediment of this high terrace reached the ocean midway between the present east and
west channels of the Sagavanirktok River. This situation suggests that the Sagavanirktok River has not oniy eroded its channel deeper during Holocene times but, in its lower $10 \mathrm{~km}$, has shifted westward. The antiquity of this older terrace is indicated by (a) extensive dissection of the feature by the river at the levels of both the present floodplain and the lower terrace, (b) the presence of stabilized sand-silt dunes on the terrace tread, (c) post-terrace drained lake
basins on the terrace tread, and (d) development of pingos, massive ice-wedge polygons, and thermokarst lakes on the terrace (pis. 6 and 12).

\section{THERMOKARST STREAM CHANNEL DEPOSITS (ts)} In areas where ice-wedge polygons are in an advanced stage of development a trough occurs directly over the
ice wedge. During the summer, the upper zone of permafrost expands laterally against the ice wedges. This
expansion is translated as upraised ridges adiacent to the ice wedge with an intervening trough. Through expansion is translated as upraised ridges adjacent to the ice wedge with an intervening trough. Through
thernokarst modification these furrows commonly are deepened, extended, integrated, and eventually form thernokarst modification these furrows commonly are deepened, extended, integrated, and eventually form

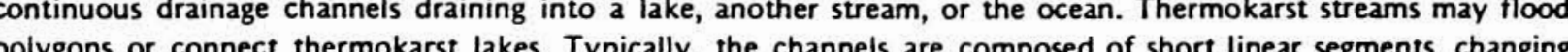
direction at angles greater than $90^{\circ}$. Channels are generaliy less than $2 \mathrm{~m}$ deep and less than $10 \mathrm{~m}$ wide. Thawing of or rill wash adjacent to the channels because the tundra vegetation is continuous to the channel banks and surface water is conducted by both low-polygon centers and raised the channel bank and bottom is vegetated. Some segments of channel have sandy gravel exposed and in transport, or this material is probably locally derived by thawing of the underlying sediment. Sediment transport is thus slow thaw the systems have gradient flow but velocities are quite low, often imperceptible.

THERMOKARST STREAM TERRACE DEPOSITS (tit)

Adjacent to some thermokarst streams with well-defined channels a subdued terrace commonly extends a few ens of meters away from either or both stream banks. Because lateral planation rarely occurs along most channels, these terraces are neither cut nor fill terraces. A distinctive characteristic of these terraces is the general lack of well-defined surface polygons, or the presence of polygonal ghosts outlining the former extent of ice wedges. Due to increased discharge and volume capacity of the stream, increased transfer of heat to the adjacent permafrost causes melting of ground ice and general surface lowering. These areas may be flooded during peak spring flow or when the
channel is blocked by ice in the fall or the spring. Partial stripping of surface silts or removal of silt and sand by piping in superpermafrost ground water may also occur but were not observed.

Lacustrine Deposits

Numerous shallow perennial lakes are a prominent feature of the Arctic Coastal Plain, and play an important role in surface dynamics acting on the terrain. The water serves as a long-term heat source, even if the lake is quite shallow, promoting thaw of the underlying permafrost. Depth of thaw is a function of the conductance of heat from the water body into the underlying sediments. The effectiveness of this process is dependent upon the total volume of water which can provide heat, as well as the surface area of the water/sediment interface over which this heat is
dispersed. Water depth, surface area, shoreline morphology, and currents play important roles in this heat transference. Ultimately massive ground ice in the upper few meters of the permafrost thaws and the surface except at former shorelines. Wind-induced lake currents further modify the lake basin by thermal erosion coupled with hydraulic removal and redistribution of sediment. This is most effective on the leeward side of the lake and along the axis of the lake normal to the dominant summer wind. These currents usually transport a mixture of silts, fine sand, and organic matter. Gravel is rarely involved. The aquatic environment (marsh or open lacustrine) is well
suited to a wide range of biota which add organic debris to the bottom sediments. Dissodged fragments of the tundra mat ranging from a few centimeters to over a meter in diameter are also rafted or shifted into the lake. The lake acts as a local sediment trap collecting wind-born silt and fine sand, as well as sediment from thermokarst streams. The origin of these lakes has been extensively discussed in the literature (Carson and Hussey, 1962; Black,
1969. 1969; Sellman and others, 1975) and a "lake cycle" is apparent. The cycle begins with a formative phase in which
low-center polygons are flooded, gradually coalescing to form a progressively larger lake. Wind-induced currents, thermal erosion, and sediment transport gradually modify the lake to an elliptical or quadrilateral outline. The lake subsequently may be partially or entirely drained and, during this phase, has an irregular shoreline and abandoned strandlines.

DEPOSITS ASSOCIATED WITH LARGE AREA LAKES (III), INTERMEDIATE AREA LAKES (Idi) AND SMALL AREA LAKES (Ids)

These three map units share the basic criteria of being perennially submerged. The distinction between the units is based on the approximate area of the lake: "large" refers to lakes greater than $0.50 \mathrm{~km}^{2}$, "intermediate" lakes are 0.15 to $0.50 \mathrm{~km}^{2}$, and "small" are lakes less than $0.15 \mathrm{~km}^{2}$. Determination of lake size and depth is important because these parameters usually influence bottom and subsurface conditions as well as indicating the potential of the lake as a winter water resource. Larger lakes may have a lens of liquid water at the bottom
throughout the winter whereas smaller lakes freeze to the bottom. The subdivisions used here attempt to distinguish chroughout the winter whereas smaller lakes freeze to the bottom. The subdivisions used here attempt to distinguish
deeper lakes having a zone which remains thawed throughout the winter (or into late winter) from those lakes that deeper lakes having a zone which remains thawed throughout the winter (or into late winter) from those lakes that
freeze to the bottom by middle to late winter and from those lakes which freeze to the bottom in early winter. The extent of winter freezing of the lakes determines whether or not a perennial thaw bulb exists in the sediments below intermediate and many large area lakes, even where the lake freezes to the bottom. Utilizing satellite and high-altitude U-2 imagery, water depths and winter ice conditions were examined for all intermediate and large area lakes in the Prudhoe Bay area. By comparing bands 5 and 7 of ERTS photography it is possible to determine if a lake is ice free, contains a submerged ice cake, or retains a surface ice cover. Lakes less than a meter deep freeze to
the bottom in winter but thaw quickly in May to lune. Lakes 1 to $2 \mathrm{~m}$ deep also freeze to the bottom in winter but the bottom in winter but thaw quickly in May to June. Lakes 1 to $2 \mathrm{~m}$ deep also freeze to the bottom in winter but
the thicker ice mass persists into June, frozen to the lake bottom, and melts downward from the surface. The deepest lakes retain thick, floating ice well into summer (Sellman, Brown and others, 1975). In this manner relative depths of lakes have been determined and, in several cases, documented by actual depth measurement (pls. 13-14). The thickness of the thaw bult affects the degree of destruction of massive ground ice. Small shallow lakes
retain submerged polygons whereas large lakes have no polygons preserved. Large and some intermediate lakes
usually have existed long enough for fine sediment to accumulate and for reworking to be extensive. The large and

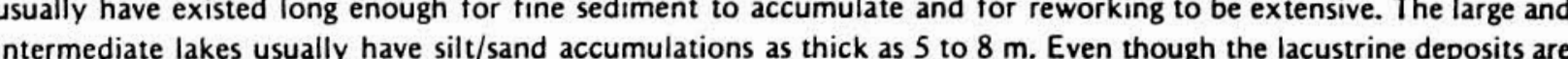
intermediate lakes usually have sitt/sand accumulations as thick as 5 to $8 \mathrm{~m}$. Even though the lacustrine deposits are
thawed to a depth of up to $5 \mathrm{~m}$ in midwinter, this thaw bulb may still be well above the perennially frozen gravels. 
DEPOSITS ASSOCIATED WITH PARTIALLY DRAINED LAKE BASINS (IdP)

Partially drained lake basins are those which, although perennially flooded, contain areas emergent above the static surface water level. This condition may occur either where several adjacent polygon centers are flooded and ridges are exposed, or where a lake formerly existed in the basin and has subsequently been partially drained. In either case, winter freezing is rapid, complece, and no thandra unit with the exception that the active layer is thicker due to summer and fall surface water (fig. 3). Where polygons are absent or very subdued, the surface deposits have been affected by thaw lake activity, silts several meters thick overlie the gravels, and massive ground ice is absent to very discontinuous in the upper 5 to $10 \mathrm{~m}$.

$$
\text { DEPOSITS ASSOCIATED WITH DRAINED LAKES (Idd) }
$$

In some cases, lake basins have been entirely drained of their water, or large segments of those basins have been drained and the remainder of the basin is either partially drained or submerged. With the exception of marshy areas and scattered ponds, he deposis of drainsins are featureless except for thermal contraction cracks (fig 4). Drained lake basins typically contain only scattered rements of former ice-wedge polygons. The basin surface may be as much as a meter below the elevation of the surrounding tundra surface. The permafrost table is static or has prograded since the drainage of the basin. The degree to which "new" polygons have developed is a relative indicator of time since the basin was drained.

$$
\text { DEPOSITS ASSOCIATED WITH ABANDONED LACUSTRINE STRANDLINES (Ida) }
$$

The deposits of former strandlines occur in areas where a lake shoreline has recently receded due to (a) a change in the shape of the lake, causing water volume readjustment, (b) the westward "migration" of the lake due to treads 10 to $20 \mathrm{~m}$ wide between scarps. This disteandoned strandlines are visible as subtle terraces with narrow apparent from the ground or air. Three separate areas of abandoned strandlines were noted to have active "young" polygons with low rims, open thermal cracks, diameters between 7 and $12 \mathrm{~m}$, and some incomplete polygon development (fig. 5). These polygons occurred on benches with broken tundra along the adjacent strand scarps.

Deposits of marine shoretines (cd)

The beach in and near Prudhoe Bay is a narrow strip of unvegetated sandy gravel with minor silt, ranging from 2 to $10 \mathrm{~m}$ in widdh, and extending virtually uninterrupted between the river deltas. On the landward side of the beach a scarp 1 to $3 \mathrm{~m}$ high is cut into the tundra, silh, and occasionadlly, into the underlys bravels. Polygonal cells of tundra are tiled loward the beach and nearby upland polygons are high canded ane to thawng of the cher the driving force of the wind causes breaking waves to continue unceasingly for days or weeks.
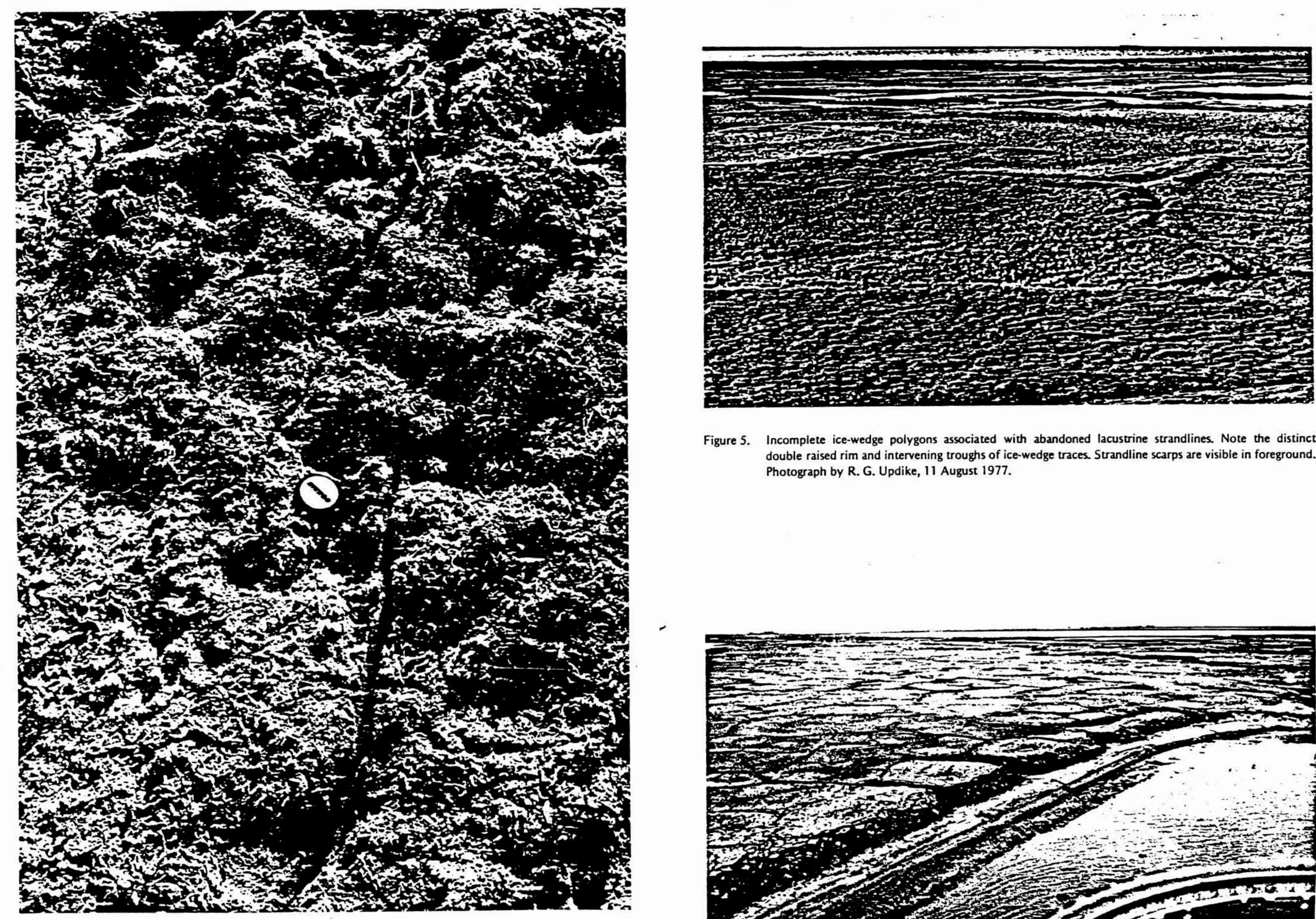

Figure 5. Incomplete ice-wedge polygons associated with abandoned lacustrine strandlines. Note the distine double raised rim and intervening troughs of ice-wedge traces. Strandline scarps are visible in foreground. Photograph by R. G. Updike, 11 August 1977 .

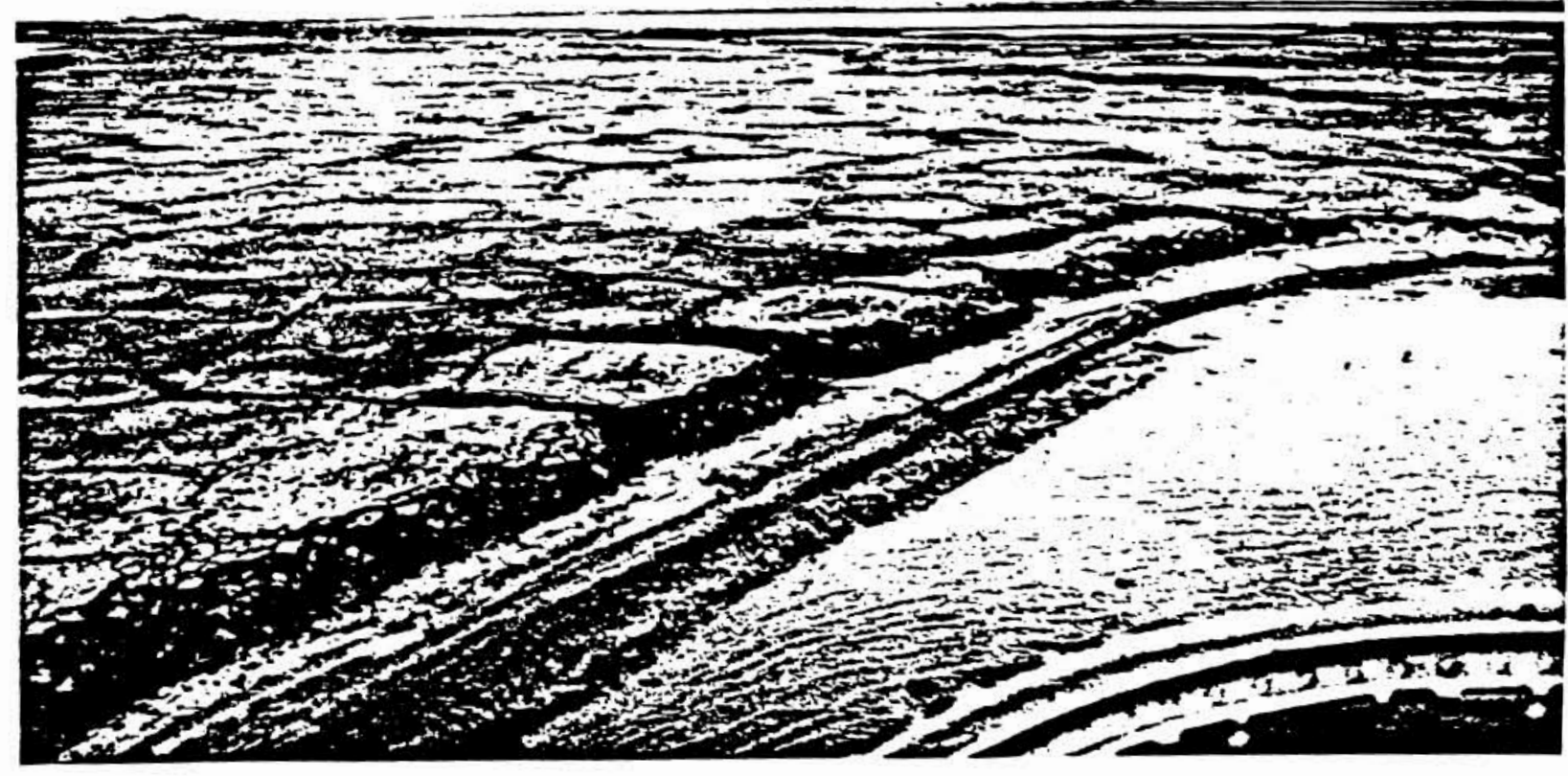

Figure 4. Close-up of the surface of a recently drained lake basin. The surface sediment consists of organic-rich silt. Seasonal frost heave causes the sediment to have a puffy texture. Note the development of incipient silt. Seasonal frost heave causes the sediment to have a puffy text
ice-wedge cracks. Photograph by R. G. Updike, 10 August 1977.

Figure 6. Low-altitude aerial view of coast at Prudhoe Bay, looking west toward the Putuligayuk River. Scarp at the lower left is approximately $6 \mathrm{~m}$ in height. Note thermokarst erosion along ice-wedge polygons. Photograph by R. G. Updike, 18 August 1977. 
Occasionally, sand and gravel bars and spits develop across small stream outlets and on points indicating east to west longshore currents (pls. 2, 3, 4, 5). The offshore submarine surface has a very gradual slope, quite similar to that of the land. Several offshore islands of sand and gravel (not here mapped) occur between 1.5 and $25 \mathrm{~km}$ from the coast.

Sands and silts of river deltas (ad and id)

Within the lower 2 to $3 \mathrm{~km}$ of the Kuparuk River and 6 to $7 \mathrm{~km}$ of the Sagavanirktok River drainages, the braided rivers grade into deltaic systems. Braided distributary channels continually change position and the entire active delta systems appear to be shifting westward. The distributary drainage pattern is due to the very low gradient of the river (less than 0 20 slope), loss of inertial velocity due to approaching sea level, water density changes, and fine sand and silt in the deltas (unit ad).

During times of greater river discharge, high tides (outer delta only), storm surges, and channel shifting, parts of the normally exposed delta are submerged. Sediments in these areas are redistributed to form subsequentiy subaerial segments of active deltas. Other parts of the delta system, compositionally identical to the active delta, stand in relief up to $1.5 \mathrm{~m}$ above the active areas. These high areas (unit id) may represent earlier periods of great mean discharge, greater silt and sand load in transport, or minor sea level transgressions. Eolian deflation

\section{Eolian deposits}

ACTIVE EOLIAN SILT AND SAND DUNES (2a)

On stable surfaces of deltas, floodplains, river terraces, and adjacent uplands of the Sagavanirktok and Kuparuk Rivers, windblown sand and silt locally accumulate to depths in excess of $10 \mathrm{~m}$. These wind-transported sediments are actively being moved and form eolian dunes. The dunes are seasonally frozen and contain interstitial ie during wher and spring. Summer thaw is followed by dessication at he surface with resultant wind-mobility of surface sediment Deph to permafrost is inknown although the in artors or large dunes are probably perennially cccur in, or downstream from, the floodplain-todelta transition zone where most of the water-taid sediment is in the snd and silt size range (pls. 2,4 , and 6 ). Although barchans and parabolic forms occur, longitudinal dunes are most typical (fig. 7). Maximum relief is approximately $5 \mathrm{~m}$, but most dune crests are less than $2 \mathrm{~m}$ above adjacent troughs. The crest of some longitudinal dunes exceed $10 \mathrm{~m}$ in length.

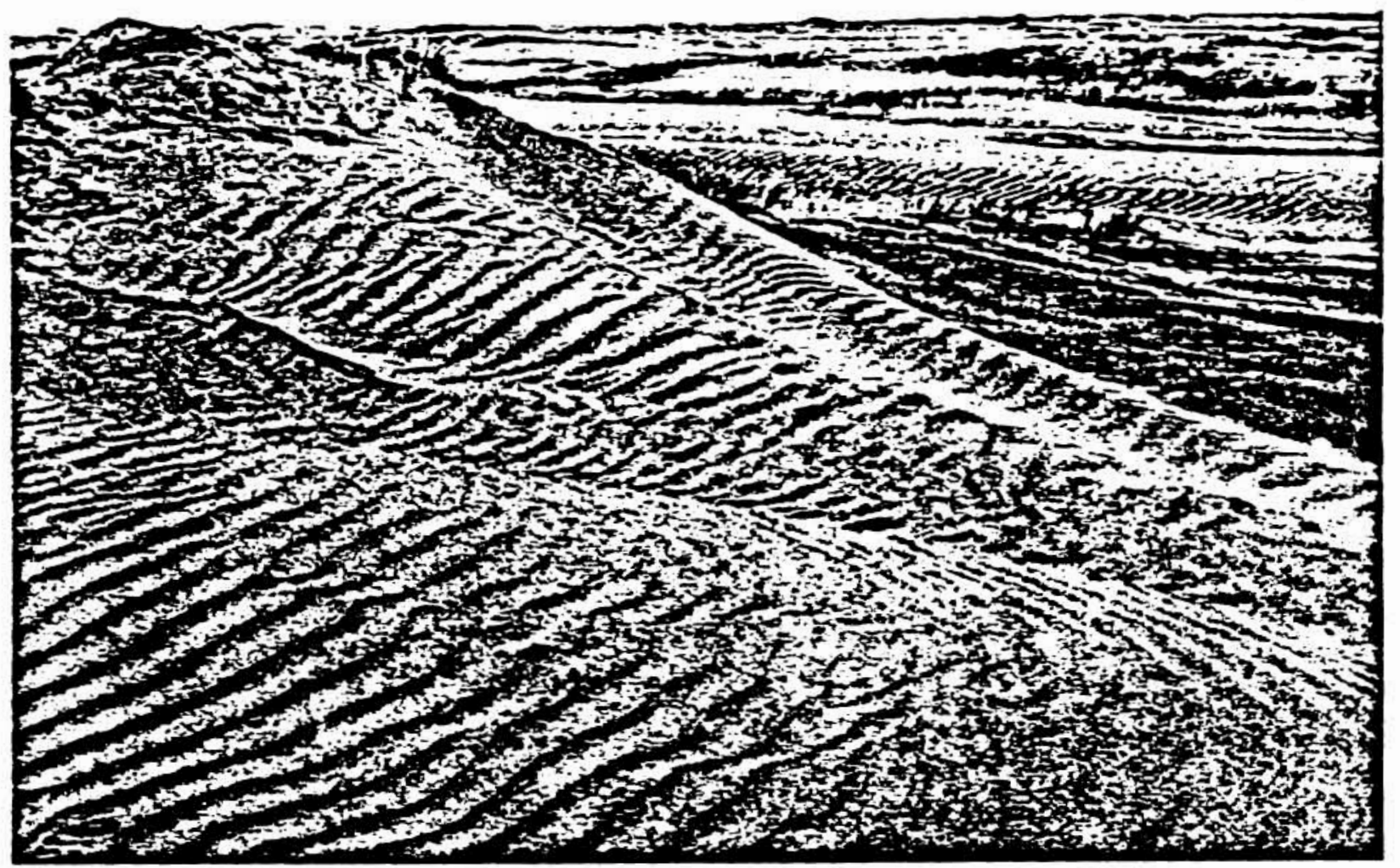

Figure 7. Active eolian deposits (aa) composed of fine sand and silt, located west of the Sagavanirktok River Jelta (plate 4). View is looking south; prevailing wind is from left to right. Note the sparse vegetation at left 20 July 1977.

INACTIVE EOLIAN SILT AND SAND DUNES (ia)

Several localities near to the Sagavanirktok and Kuparuk Rivers are covered by stabilized dunes that are compositionally identical to active dunes. However, the inactive dunes are typically covered by tundra vegetation except along oversteepened slopes. Permafrost depth and type is unknown and ice-wedge polygons are generally not visible.

Dune form is highly subdued compared to active dunes; however, dimensions and forms are similar. Although locally active, most dunes of this unit are stabilized. The area covered by inactive dunes is more extensive than that and floodplin, perhaps implying that the deltas were formeriy more extensive to the east or northeast. Dunes on the lower river terraces indicate that at least part of the eolian deposition occurred during the present cycle of river erosion. Dune form consistently indicates east to northeast winds regardless of location.

SAND AND SILT ASSOCIATED WITH DEFLATION BASINS (db)

Deflation hollows and basins are common within areas of active and inactive dunes. These areas are relatively flat, unvegetated, wind-scoured depressions, bounded by truncated dune margins (often with oversteepened slopes). Eroded remnants of former dunes are exposed in the basins (fig. 8). Although most basins are less than $100 \mathrm{~m}$ long.

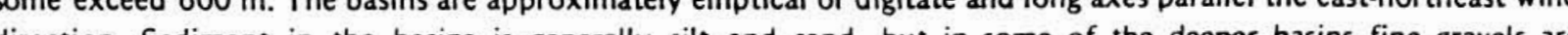
direction. Sediment in the basins is generally silt and sand, but in some of the deeper basins fine gravels are produces shallow lakes in these basins.

Pingos

Pingos are intrapermafrost features which, at Prudhoe Bay, have surface expression as isolated hills ranging up to $9 \mathrm{~m}$ in height. They are oval in plan view and vary from about 50 to $600 \mathrm{~m}$ in length and 30 to $380 \mathrm{~m}$ in width. sediments begins to freezem downward from the ground surface. The volume of saturated sediment becomes entirely confined between the downward-freezing zone and the underlying impermeable permafrost table. Excess pore water is expelled ahead of the advancing freezing front resuiting in excess hydrostatic pressure. As the excess water is frozen in a roughly lenticular ice mass, the overlying permafrost is arched upward due to the underlying hydrostatic (a) Mackenzie Delta this type of pingo is commonily associated with

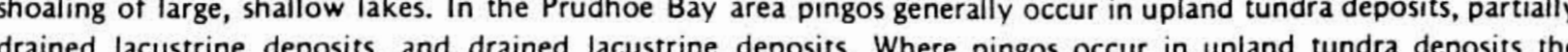
drained lacustrine deposits, and drained lacustrine deposits. Where pingos occur in upland tundra deposits the

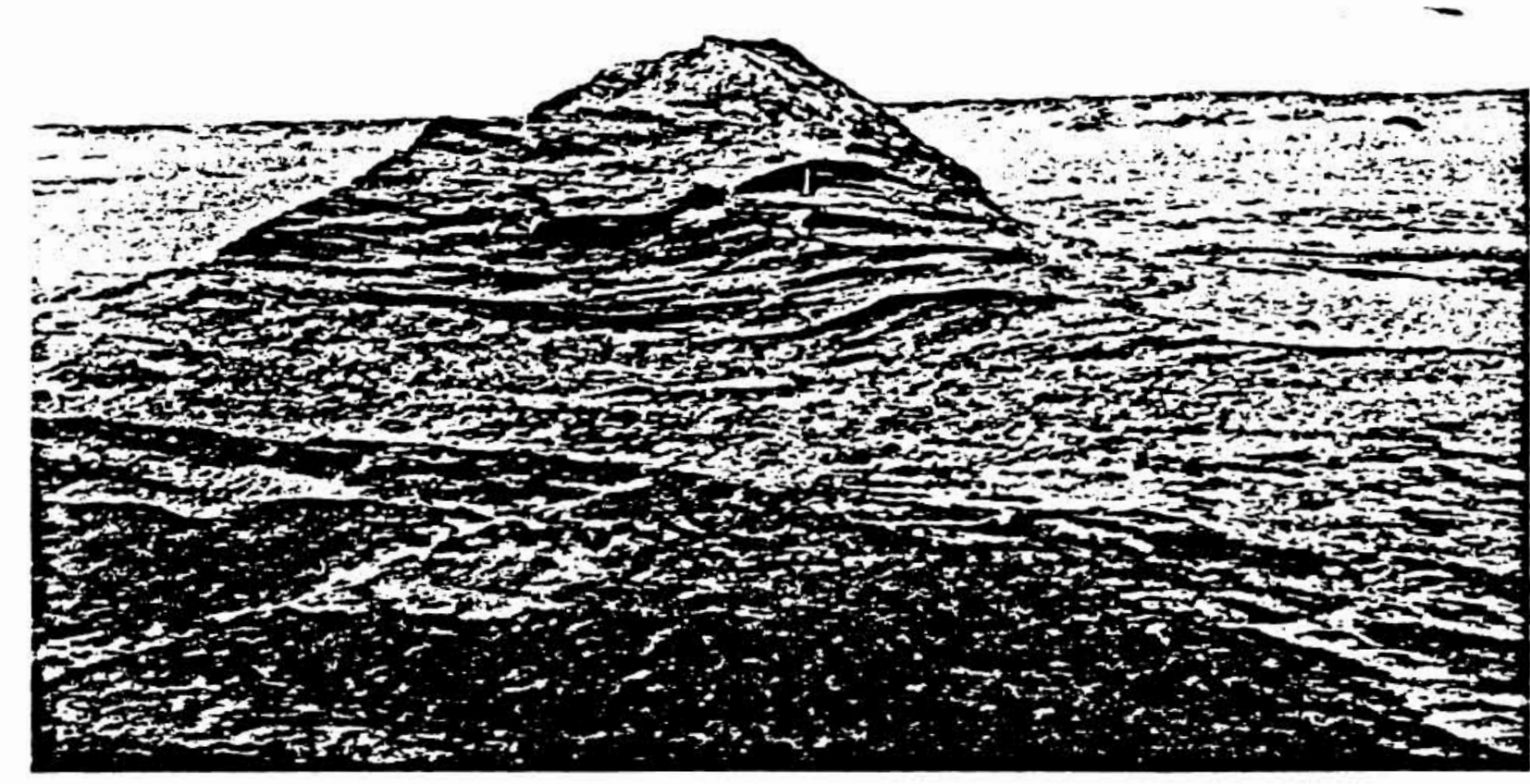

Figure 8. The remnant of an eolian dune, now partially removed by deflation. Floor of deflation basin (db) is in foreground. Dunes remnant was partially frozen. Surface of basin was near saturation, and was bein the Sagavanirktok River delta (plate 4). Photograph by R. Updike, 20 July 1977.

HYDROLOGY

General statement

A number of hydrologic studies have been made in the Prudhoe Bay area. Most have been carried out to determine the occurrence of water resources and to indicate where year-round reliable sources of potable water exist. In the past, reliable winter supplies of potable water have been very difficult to obtain due to the extrem arctic conditions and the existence of permafrost. This section briefly summarizes the hydrology of the Prudhoe Bay area. Hydrologic data were obtained from
several sources including USGS, BP, ARCO, and Arctic Gas Alaska (AGA).

Rivers

The Sagavanirktok River drains an area of roughly $12,000 \mathrm{~km}^{2}$. On the border of the study area it consists of baided channel Few mose the floodplain. For most of the winter and spring the river is completely ice-covered and there is no surface evidence initial thaw is complete, flows decline to normal summer levels. Flows peak again during occasional sum Al ster During the fall, discharge gradually declines as the river freezes and groundwater base flow becomes minimal. A few specific studies have been conducted on the Sagavanirktok River in the winter to determine the occurrence and extent of free-water pools and closely associated groundwater zones beneath the river ice. These studies were conducted to determine if there are any reliable volumes of winter water beneath the river ice and above the permafrost table. These studies indicate 4 hat pools of free water and associated groundwater zones $d 0$ exist and appear to be most prominent at meander loops within the braided system. Based on borings, Sherma during lanuary and April of 1969 . Results show that a thawed zone approximately $100 \mathrm{~m}$ wide and $7 \mathrm{~m}$ thick in indicates the presence of thawed ground beneath the river ice (Harry Haywood, 1977, personal comm.1. Temperatures were measured in boreholes to delineate the distribution of the thawed zone. In April, 1976, geophysical exploration was conducted by AGA. Using electromagnetic (VLF radiohm) and shallow resistivity methods near ARCO's operaton center and Kodiak Com diny rachilies, groundwater zones beneath the stream bed

The Kuparuk River drains an area of approximately $8,000 \mathrm{~km}^{2}$. It has been gaged by the USGS since June, $1971,16 \mathrm{~km}$ south of its mouth at Gwyder Bay. Streamflow records (U. S. Geological Survey, 1971-1976) indicate that the river floods during early June. Mean flow for the month of June is 12,500 cubic feet per second (cfs)(350 cubic meters per second, $\left.\mathrm{m}^{3} / \mathrm{s}\right)$. Peak flows for the past six years of record have ranged from $22,600 \mathrm{cts}\left(640 \mathrm{~m}^{3} / \mathrm{s}\right)$ to $82,000 \mathrm{cfs}\left(2,300 \mathrm{~m}^{3} / \mathrm{s}\right)$ (average of $\left.55,000 \mathrm{cfs}, 1,600 \mathrm{~m}^{3} / \mathrm{s}\right)$, occurring from June 7 to June 17. During the Throughout the fall, flows decline gradually as freeze-up occurs, and as snowmelt runoff and gondwater fib decline.

Specific studies on the winter hydrology of the Kuparuk River have been less extensive than those on the Sagavanirktok River. Three holes were drilled by BP on the river ice during January, 1976, and AGA performed geophysical surveys in April, 1976. Both surveys indicate the presence of disconthrous swbice pools and thawe The Putuligayuk River is a relatively small local arctic river that flows into Prudhoe Bay from the south
, draining approximatly 450 square $\mathrm{km}$. The fiver has been monitored since May, 1970 , at a point $11.7 \mathrm{~km}$ south middle lune and average $3,750 \mathrm{cfs}\left(110 \mathrm{~m}^{3} / \mathrm{s}\right)$. Normal summer flows are relatively low ranging from 1 to $100 \mathrm{cfs}$ ( 0.03 to $2.8 \mathrm{~m}^{3} / \mathrm{s}$ ) and flow ceases by late September-early October.

Water quality in all three rivers varies seasonally. Runoff in June from snowmelt in both the Kuparuk and Putuligayuk Rivers is excellent in quality, varying from 24 to 113 miligrams per liter (mg/l) in total dissolved solid (U. S. Geological Survey, 1971-1976). Flooding during the June thawing period imparts average suspended sediment summer flows in August the Kuparuk and Putuligayuk Rivers have higher average torl dissolved solid of 728 and $171.3 \mathrm{mg} / 1$, respectively. Suspended sediment concentration in August for these rivers is less than $10 \mathrm{mg} / 1$. Data for winter months indicate that total dissolved solids can reach as high as several hundred $\mathrm{mg} / 1$, evidently caused by freeze concentration. 
Taliks not clearly associated with existing surface water bodies have been penetrated by drillers. These random unfrozen zones appear to be either remnant or incipient features where permafrost is either degrading or aggrading
depending upon changing geologic and climatic conditions (Williams, 1970). Like other taliks, these are isolated in or above the permafrost. Water in the taliks is usually saline, either originating from ionic concentration throug freezing or by melting of saline permafrost.

\section{Conclusions}

The natural occurrence of water in the Prudhoe Bay area is very limited for more than 6 months of the year because of the extreme environment. Surface water of good quality is readily available in rivers and lakes througho the summer. Groundwater occurs below these surface water bodies in tallys above the permatrost lo varying depths. Their extent lape tals.
and poor in lake taliks. In winter, potable water demands of the Prudhoe Bay operators are quite large in comparison to natural supplies. Rivers have very low (if any) flows in the winter. Groundwater in taliks directly below the rivers is available and of good quality, but is limited to discontinuous zones in the winter. In addition, well maintenance on the river floodplains is difficult. Many lakes freeze to the bottom in the winter. Deeper lakes have limited free water storage
in the winter and tend to have concentrated impurities. Taliks beneath lakes and those of random occurrence are in the winter and tend to have concentrated impurities. Taliks beneath lakes and those of random occurrence are
difficult to locate, usually limited in extent and have a high total dissolved solids concentration.

The best method for providing reliable year-round potable water supplies is by development of artificial reservoirs. Construction of reservoirs in gravel deposits near the Kuparuk (fig. 9) and Sagavanirktok Rivers is being carried out by BP and NANA Corporation, respectively. ARCO has deepened an existing lake and draws water from the Sagavanirktok River to recharge the lake-reservoir, except during spring break-up when the river becomes turbid.

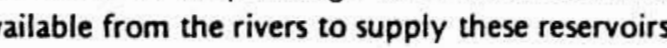

EXPLANATION OF DERIVATIVE MAPS, PLATES 13 AND 14

Two of the prime concerns of this study are to evaluate potential sources of construction material (sand/gravel aggregate) and potable water. Plates 13 and 14 are intended to delineate areas which may be of specific value in hese two concerns

In the discussion of the surficial geology it was noted that sand and gravet underlie essentially the entire area thest areas for excavation of this gravel the following criteria were considered:

a) maintain the natural integrity of the river floodplains to minimize modification of existing hydraulic

geometry and sediment transport characteristics

b) prevent damage to the aquatic wildifie habitat

d) utilize areas where the seasonally active layer is thickest, i.e., where the gravels are seasonally thawed to

if permafrost is to be encountered, locate areas where massive ground ice will be minimal (benefiting slope stabilization and maximum gravel yardage per finite volume excavated

These criteria are best fulfilled in certain restriceed areas of the active and inactive floodplains (units af and if of the Kuparuk and Sagavanirktok Rivers. Secondary selection sites are less desirable considering economic and engineering aspects, but are both feasible and environmentally sound. In addition to the prime sand/gravel sites, areas where reasonably well-sorted gravel-free sand can be obtained are indicated on the plates.

Alternatives for year-ound potable water supply have been discussed above. Existent lakes may be utilized as a seasonal supply until freezedown, or, if of sufficient area and depth to prevent total freeze, may be perennia so:rces. Centain lakes, by virtue of the, proximily to a aver and their accessibility, may be deepened by excavation

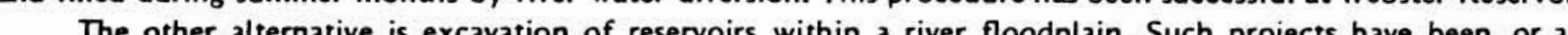
beng, completed on all three rivers. The advantages include (a) utilization of the excavated gravels for construction, (b) good quality water, (c) gravity recharge from the adjacent river, and (d) ease of excavation, maintenance, and expansion. Design and location must be closely monitored so that disturbance of the river dynamics does not occur.

MAN-INDUCED ENVIRONMENTAL HAZARDS

Several potential environmental problems are associated with man's activities in the Prudhoe Bay area. The following brief discussion summarizes some of those problems that are most apparent. Wind-transported silt (loess) is being generated from haul roads, and is carried downwind over the tundra causing inhibition of vegetation growth change in surface abedo, and resultane modifcation of the hermal equilibrium of the ground. On segments of tundra by runoff and as an aerosol. During dry periods, the combination of the road oil and wind ceflation of sith produces an oil-coated loess. Aerosols and particulate matter from other areas of activity such as drill pads and vehicle repair sites are also carried downwind onto the tundra. Contamination of natural waters and reservoirs can result from all of these processes. photo was taken. The lower fluvial terrace (Its) is visible beyond the scarp in the upper part of the Photography by R. Updike, 18 August 1977 .
Picture. The pines at the bottom of

Lakes

Lakes were the first hydrologic feature in the area to be explored for a source of water. They cover a significant portion of the area and have a wide range of sizes and shapes. The majority of stabilized lakes have a rounded rectangular shape with their long axis oriented approximately $13^{\circ}$ west of north. They range from about 1,100 $\mathrm{m}$ to $2,400 \mathrm{~m}$ in their longest dimension and $750 \mathrm{~m}$ to $1,200 \mathrm{~m}$ in width. There are many smaller ponds with
lengths of a few tens of meters. Most lakes are very shallow, being less than $2 \mathrm{~m}$ deep (pl. 13-14). Lakes deeper than lengths of a few tens of meters. Most lakes are very shallow, being less than $2 \mathrm{~m}$ deep (pl. 13-14). Lakes deeper than
$2 \mathrm{~m}$ can have free water between the winter ice cover and the sediment bottom.

Sherman (1973) studied a few lakes in the vicinity of ARCO operations center during June, 1969. He found
S that lakes between $2.5 \mathrm{~m}$ and $3.5 \mathrm{~m}$ deep had as much as $1.5 \mathrm{~m}$ of free water beneath $2 \mathrm{~m}$ of ice. As much as $4 \mathrm{~m}$ of

sediment below the lakes was unfrozen.
British Petroleum surveyed Big Lake, located $8.8 \mathrm{~km}$ southwest of Prudhoe Bay, in February, 1970 (Harry
Haywood, 1977, personal comm.), and data were obtained from 21 borings. The thickness of surface ice varied from Haywood, 1977, personal comm.), and data were obtained from 21 borings. The thickness of surface ice varied from
0.45 to $1.68 \mathrm{~m}$. In a few places, a small amount of free water was found below the surface ice. The lake bottom

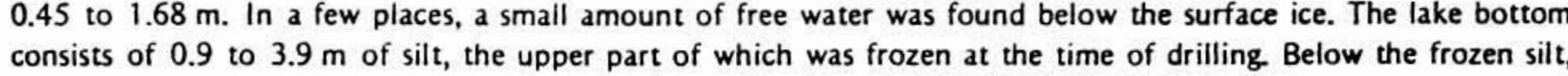
consists of 0.9 to $3.9 \mathrm{~m}$ of silt, the upper part of which was frozen at the time of drilling Below the frozen silt,
thawed sediments commoniy occurred to depths ranging from 1.4 to $6.1 \mathrm{~m}$. The water in the thawed sediment at one locality was poor in quality, containing $3,440 \mathrm{mg} / 1$ chlorides.

\section{Groundwater}

In the Prudhoe Bay area continuous permafrost, which extends several hundred meters below the surface, affects groundwater by limiting its occurrence. movement, and quality. Groundwater commonly occurs within perennially thawed sediments, or taliks, which depress the permafrost table beneath surface water bodies. When the lake or river is thawed, heat is continuously conducted from the water to the underlying sediment. Throughout the
year the water body also insulates the sediment by decreasing heat loss to the atmosphere. These taliks are more
restricted in winter (Sherman, 1973).

Summer data on the depths of taliks below rivers are lacking. In the winter, groundwater appears to occur in
antinuous zones of limited extent. Groundwater quality beneath rivers is good throughout the year because it is associated with surface flows. These river taliks are quite permeable because of the predominance of sand and gravel. Restricted groundwater also occurs under lakes and usually the deeper lakes are underlain by a thicker talik. The water quality of these taliks is poor.

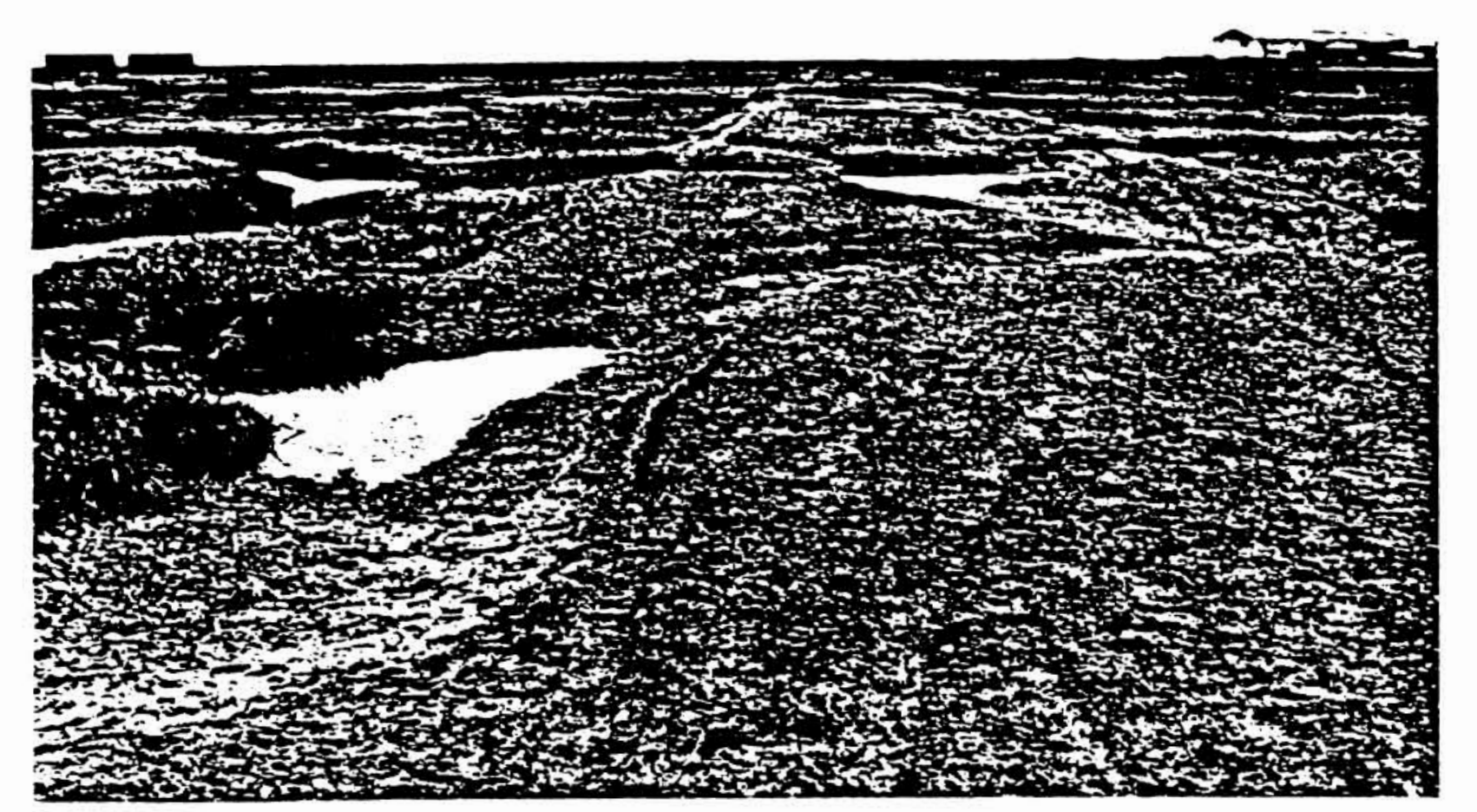

Figure 10. Abandoned road near Deadhorse, rendered unusable due to thermokarst subsidence along ice-wedge polygons. The problem would have been averted by proper thickness of gravel fill. Photograph by R. G. 
Natural drainage systems, particularly thermokarst streams, may have their flow either impeded or accelerated by the oil field development. Particularly, roadways and pads have not, in some cases, allowed for natural drainage, resulting in ponding and the initial stages of thermokarst subsidence. Elsewhere, drainage channels have been too

Several areas of excavation (e.g.g.s Sagavanirktok River floodplain, Putuligayuk River oxbows) have produced piles, and the cutting and removal of gravel bars, (b) stream grad dynamics by deep barrow pits, high storage extraction, (c) width to depth ratio changes by scraping and dredging, and (d) artificial stabilization of natural cutbanks.

The process of excavation and removal of sand and gravel from an active floodplain modifies the sediment load characteristics of the stream. Suspended load-is increased due to agitation of the excavated sediment, giving July, 1977. Further, the sand and gravel bo non made concerning rates of bed load transport on these rivers but if rates are low, long-term disruption of the rivers' transport budgets has occurred.

The thawing of permafrost liberates pore moisture which was bonding the sediment, and may also melt massive ground ice. The results are loss of bearing strength and differential ground subsidence. This process is often accidentally initiated or accelerated by oil field activities. Where gravel pad construction has been insufficiently thick, heat how into the ground is entalced, extending he depth of the active layer (fig. 10). Reservoirs greatly subsidence. Artificial modification of lake basins by excavation, fill, or causeway construction can alter lake circulation patterns. This may cause shoreline modification, thawing of permafrost beneath or adiacent to the lake, and thicker lake ice in restricted areas.

Winter haul roads across river ice or frozen lakes compact or remove snow cover, resulting in thicker ice development this may sead of sub-ice channels and pools, restricting movement of overwintering fish, and could cause fish kills due to oxygen deficiency in restricted pools.

REFERENCES CITED

Black, R. F. 1964, Gubik Formation of Quvery age in northern Alaska: U. S. Geol. Survey Prof. Paper 302-C. $91 \mathrm{p}$

Britton, M.E., 1958, Vegetation of the arctic tundra in Arctic Biology: Oregon State Coll., Ann. Biology Con,

Carson, C. C., and Hussey, K. M., 1962, The oriented lakes of arctic Alaska: Jour. Geology, V. 70, p. $417-439$

Carter, L. D., Repenning, C. A., Marincovich, L. N., Hazel, J. E., Hopkins, D. M., McDougall, K., and Naeser, C. W., U. S. Gubik and pre-Gubik Cenozoic deposits along the Colvilie River near Ocean Point, North Slope, Alask

Churchill, E. D., 1955, Phytosociological and environmental characteristics of some plant communities in the Umia region of Alaska: Ecology, V. 36, p. 606-627.

Drew, J. V., Tedrow, J.C.F., Shanks, R. E., and Koranda, J. J., 1958, Rate and depth of thaw in Arctic soils: Am. Geophys. Union Trans., V. 39, p. 697-701.

Hopkins, D. M., 1967, Quaternary marine transgressions in Alaska in Hopkins, D. M., ed., The Bering Land Bridge Stanford, Stanford Univ. Press, p. 47-90.

Hopkins, D. M., Karlstrom, T.N.V., and others, 1955, Permafrost and groundwater in Alaska: U. S. Geol. Survey Prof. Paper 264F, p. 113-146.

Hussey, K. M., and Anderson, G. S., 1963, Environment and distribution of thermal relief features in the Northern Foothills Section, Alaska: Office of Naval Research Contract Report, unpubl., 76

Lachenbruch, A. H., 1962, Mechanics of thermal contraction cracks and ice-wedge polygons in permafrost: Geol. Soc. America Spec. Paper 70, $69 \mathrm{p}$.

Mackay, J.R., 1966, Pingos in Canada, in Permafrost Internat. Conf., Lafayette, Ind., 1963, Proc.: Natl. Acad. Sci.-Natl. Research Council Pub. 1287, p. $71-76$.

Northern Engineering Services $C_{0} .$, Ltd., 1976 , Geophysical investigations on the rivers of the Arctic Coastal Plain in Alaska: Draft report for Arctic Gas Alaska.

O'Sullivan, I. B., 1961, Quaternary geology of the Arctic coastal plain, northern Alaska: lowa State Univ., unpub. Ph.D. thesis, 191 p.

Pewe, T. L., 1975, Quaternary geology of Alaska: U. S. Geol. Survey Prof. Paper 835, 145 p.

Sellman, P. V., Brown, J., Lewellen, R. 1., McKim, H., and Merry, C., 1975, The classification and geomorphic implications of thaw lakes on the Arctic Coastal Plain, Alaska: U. S. Army C.R.R.E.L. Res. Rept. 344, 21 p.

Sellman, P. V., Weeks, W. F., and Campbell, W. I., 1975, Use of side-looking airborne radar to determine lake depth on the Alaskan North Slope: U. S. Army C.R.R.E.L. Special Rept 230, 6 p.

Sherman, R. G.. 1973, Groundwater supply for an oil camp near Prudhoe Bay, Arctic Alaska in Second Permafrost Internat. Conf., 1966, Proc.: Natt. Acad. Sci.-Natl. Research Council, p. 469-472.

Spetzman, L A., 1959, Vegetation of the Arctic Slope of Alaska: U. S. Geol. Survey Prof. Paper 302B, p. B19-B58. Stoneley, R., 1970, Discussion, in Lachenbruch, A. H., Thermal consideration in permafrost, in Adkison, W. L., and Brosge, M. M., eds., Proc. Seminar on the North Slope of Alaska: Los Angeles, Pacific Sec. Am. Assoc. Brosge, M. M., eds., Proc. Seth
Petroleum Geologists, p. 13-14.

U. S. Geological Survey, 1971-1976, Water resources data for Alaska water year (as indicated).

Wiggins, I. L., and Thomas, J. H., 1962. A flora of the Alaskan Arctic Slope: Univ. of Toronto Press, Arctic Inst.

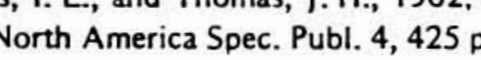

Williams, J. R., 1970, Groundwater in the permafrost regions of Alaska: U. S. Geol. Survey Prof. Paper 696, 83 p. 


\begin{tabular}{|c|c|c|c|c|c|c|c|c|c|c|c|}
\hline $\begin{array}{l}\text { ENGINEERING } \\
\text { GEOLOIIC } \\
\text { UNIT }\end{array}$ & STRATIGRAPHY & $\begin{array}{l}\text { GRAIN SIZE } \\
\text { DISTRIBUTION }\end{array}$ & ICE CONTENT AND TYPE & $\begin{array}{l}\text { MOISTURE CONTENT } \\
\text { OF } \\
\text { ACTIVE LAYER }\end{array}$ & $\begin{array}{l}\text { ORGANIC } \\
\text { CONTENT }\end{array}$ & $\begin{array}{l}\text { VEGETATION AND } \\
\text { SOL AN } \\
\text { CHARACTERISTICS }\end{array}$ & DRAINAGE/SURFACE WATER & $\begin{array}{l}\text { DEPTH OF } \\
\text { ACTIVE } \\
\text { LAYER }\end{array}$ & $\begin{array}{l}\text { BOUNDARY } \\
\text { CONDITIONS }\end{array}$ & SLOPE AND SLOPE STABLLITY & $\begin{array}{l}\text { BEARING STRENGTH, } \\
\text { THAWED }\end{array}$ \\
\hline 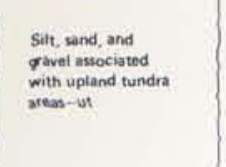 & 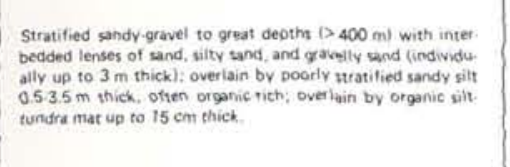 & 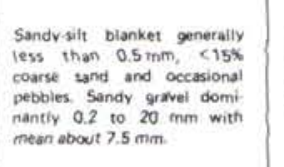 & 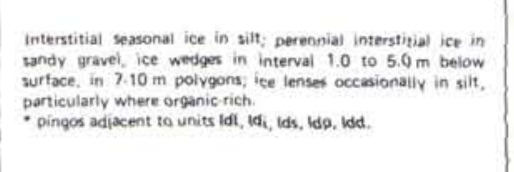 & 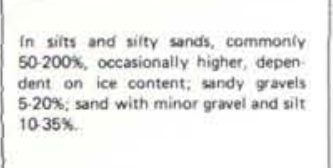 & 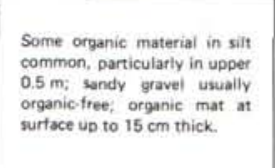 & 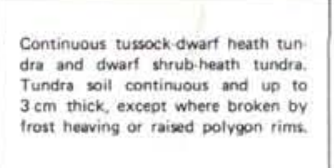 & 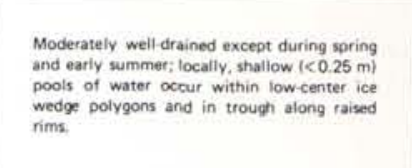 & 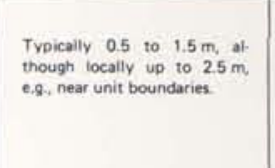 & 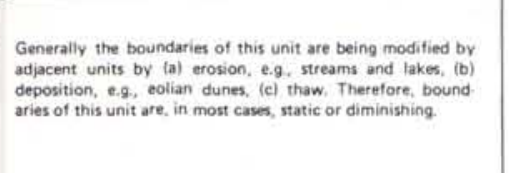 & 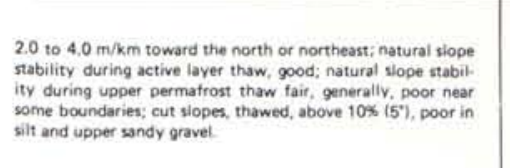 & 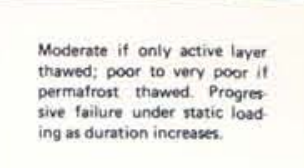 \\
\hline 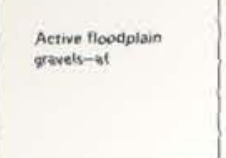 & 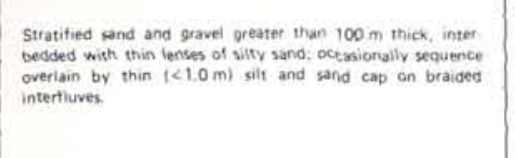 & 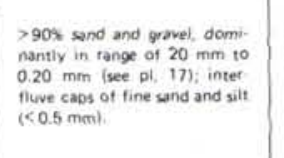 & 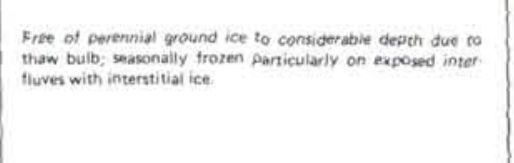 & 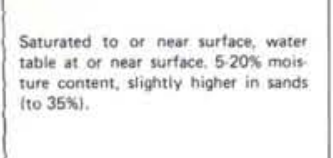 & 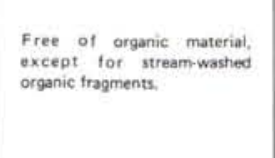 & 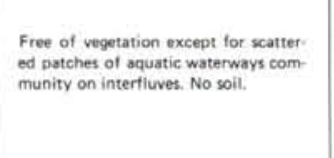 & 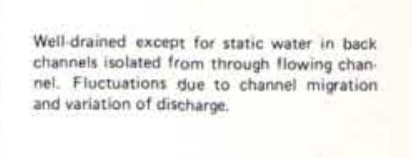 & 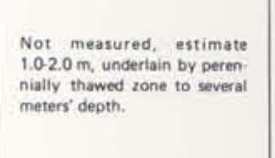 & 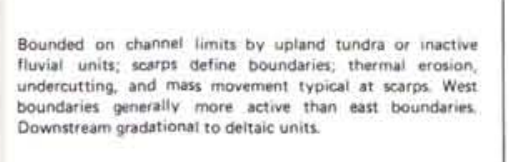 & 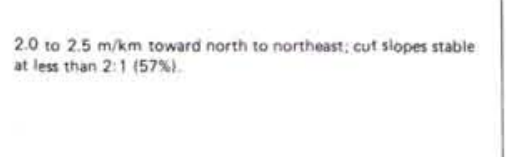 & 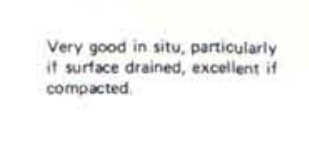 \\
\hline 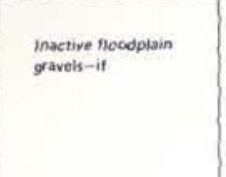 & 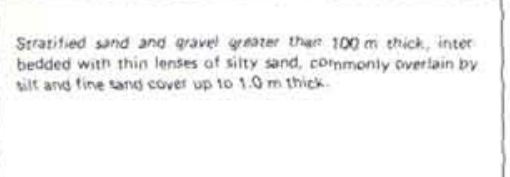 & 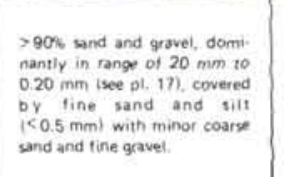 & 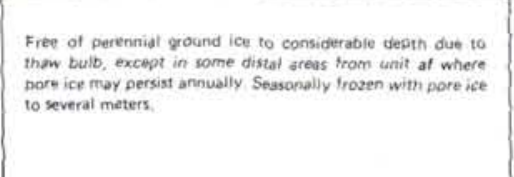 & 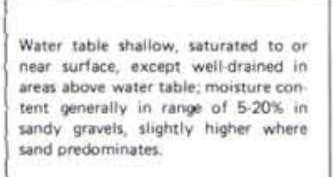 & 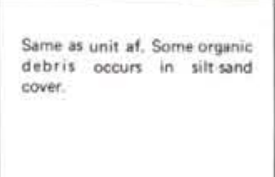 & 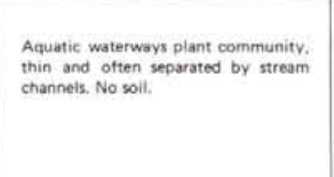 & 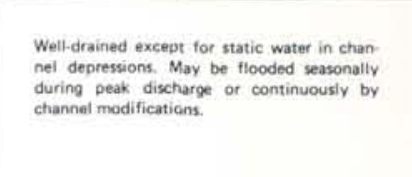 & some sunit at. & 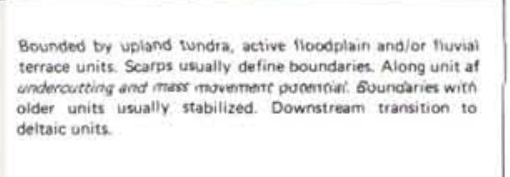 & some as unit at. & some a vunit at. \\
\hline 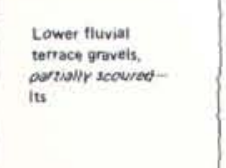 & 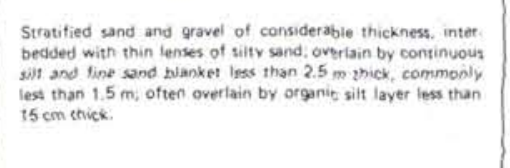 & smesesuntiti. & 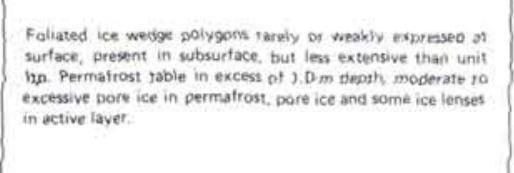 & 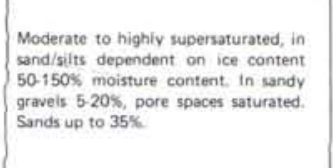 & 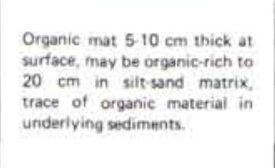 & 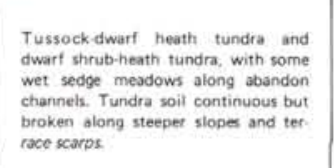 & 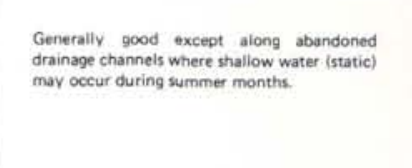 & 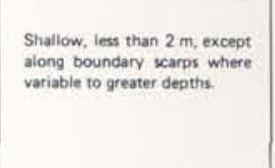 & 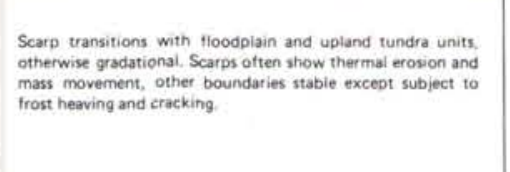 & 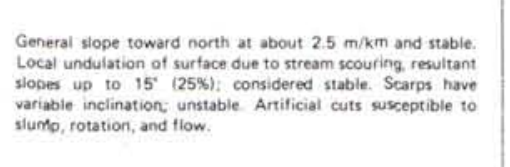 & 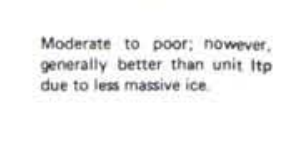 \\
\hline 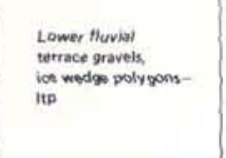 & 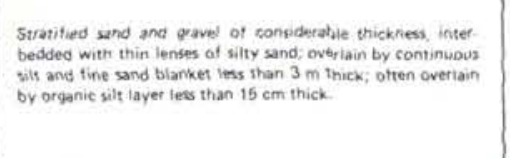 & someravinitit. & 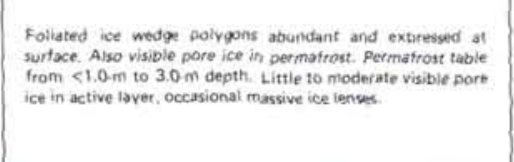 & Smemes vonit the & Sume sunit thes. & 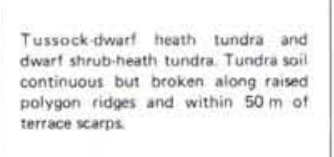 & 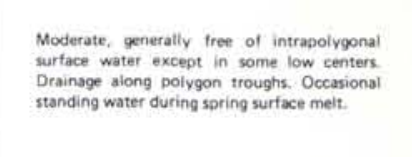 & some as unit tit. & Sume o vunit tie. & 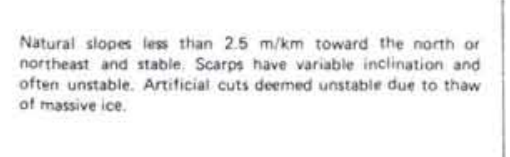 & 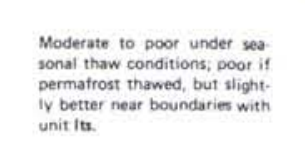 \\
\hline 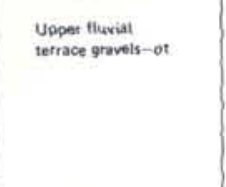 & 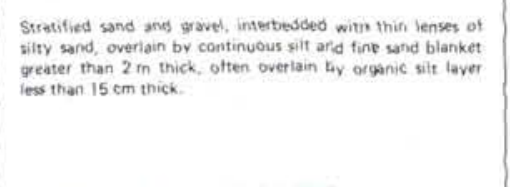 & Somere anotiti. & 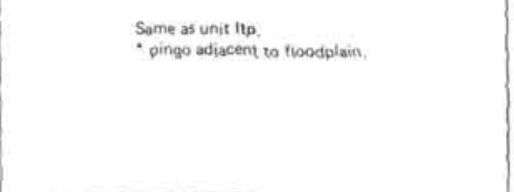 & 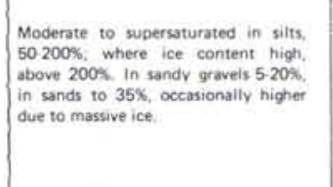 & somes sunt the & 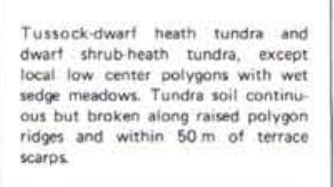 & 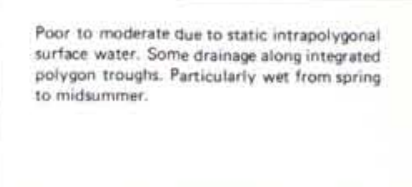 & smenes worit the & 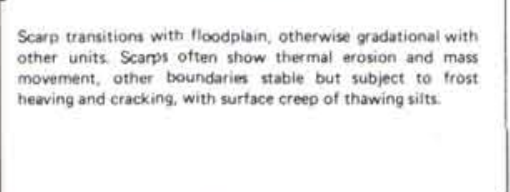 & Some sunit the & 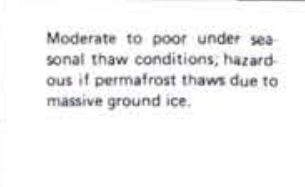 \\
\hline 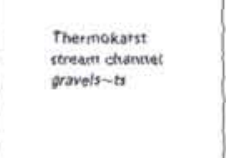 & somen wumine & somentumerer. & 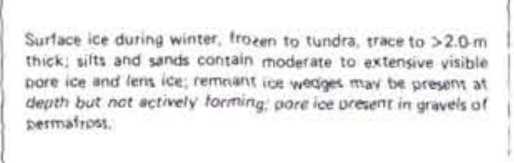 & 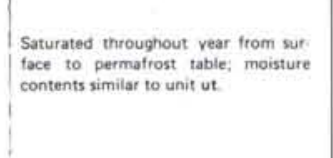 & 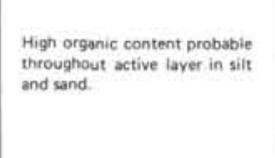 & 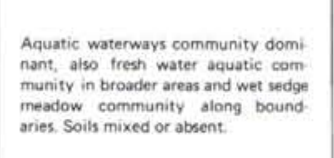 & 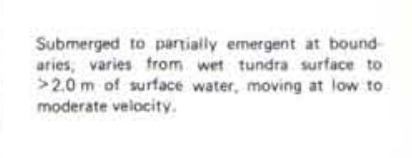 & 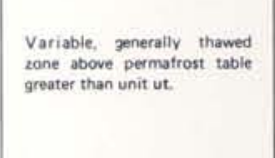 & 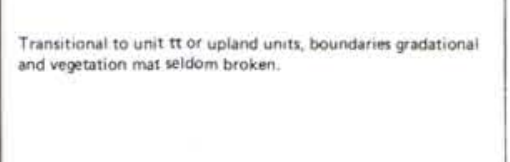 & 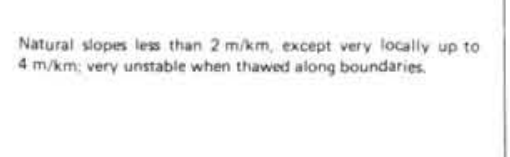 & 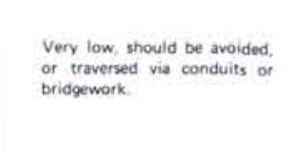 \\
\hline 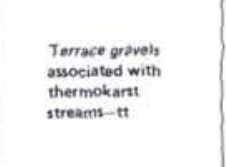 & sumes unotic ut. & somese ancuicut. & 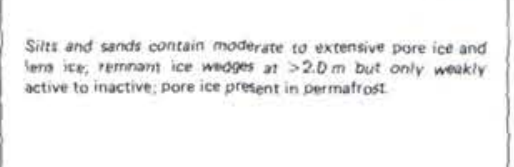 & 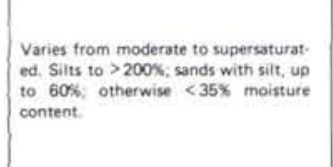 & 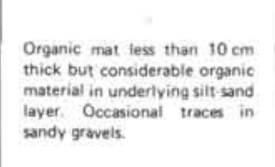 & 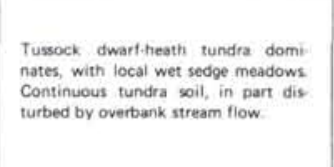 & 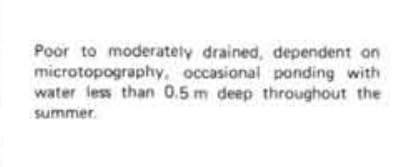 & 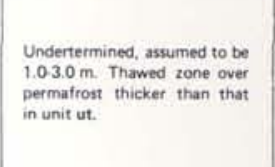 & 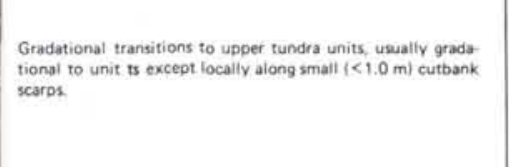 & 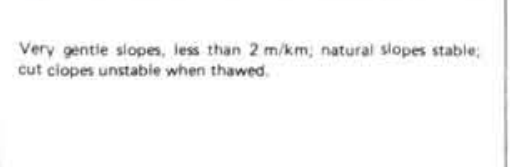 & 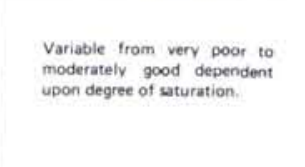 \\
\hline 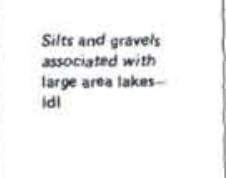 & 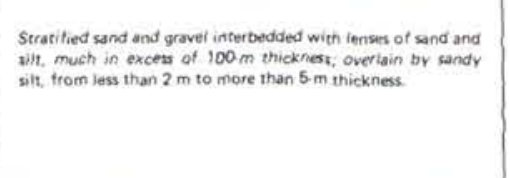 & 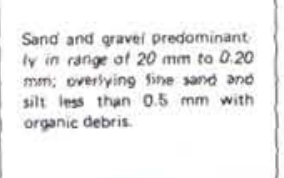 & 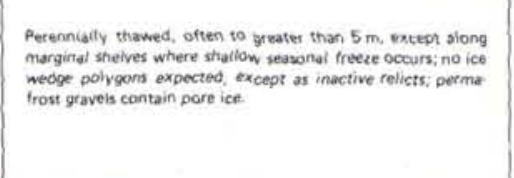 & Perembialy w wurnate. & 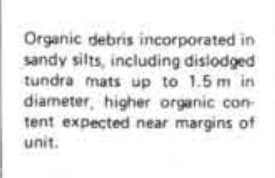 & 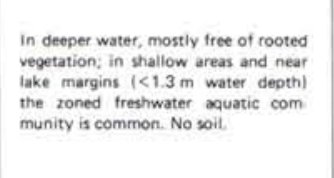 & 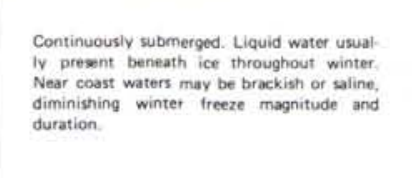 & 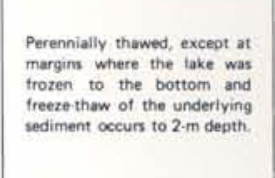 & 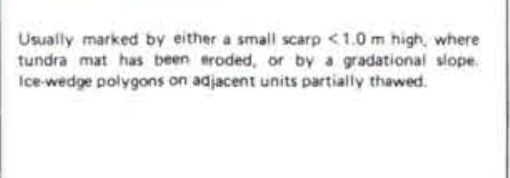 & 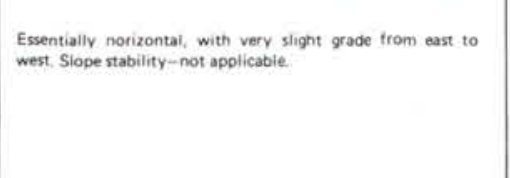 & Not sopicieble. \\
\hline 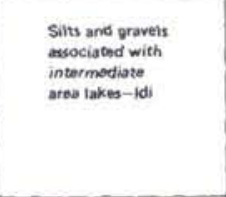 & Somere w viri tat. & Somen wuit tat. & 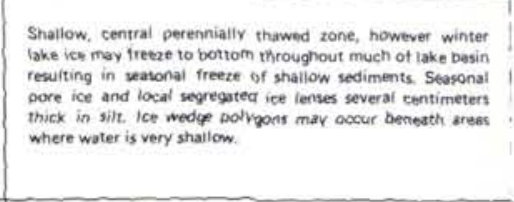 & 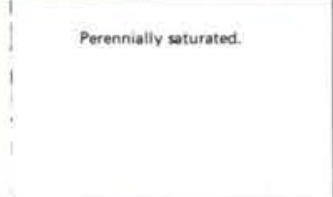 & Smemesurin tat. & Somes sunit tat. & 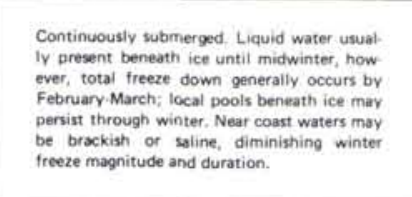 & 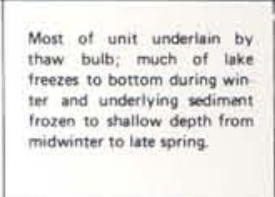 & Some sunit tot. & Some sun unit tat. & Not appicicable. \\
\hline 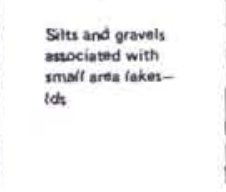 & 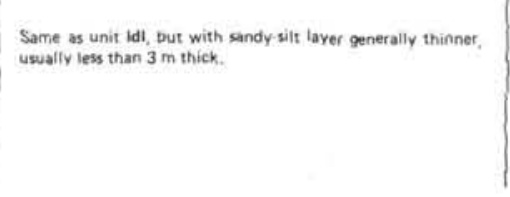 & Somere un viti toll. & 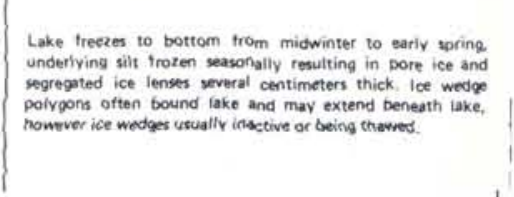 & Perenonially solvarated. & 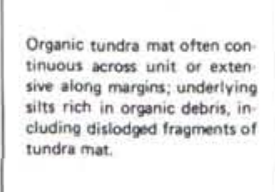 & 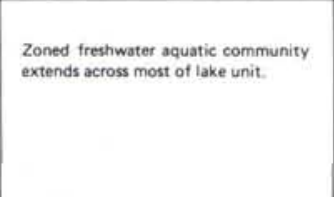 & 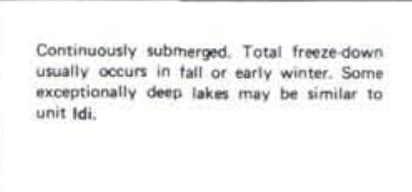 & 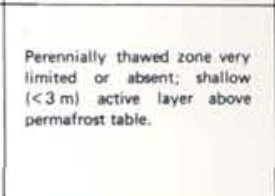 & 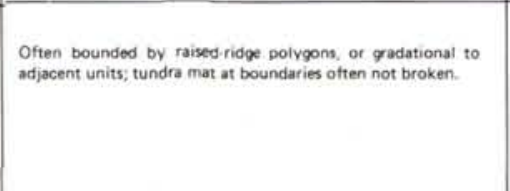 & 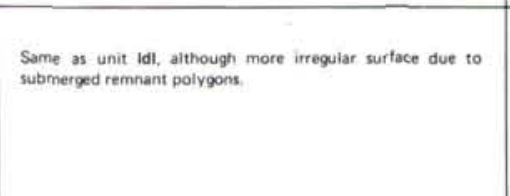 & Nor sopicicabie. \\
\hline
\end{tabular}




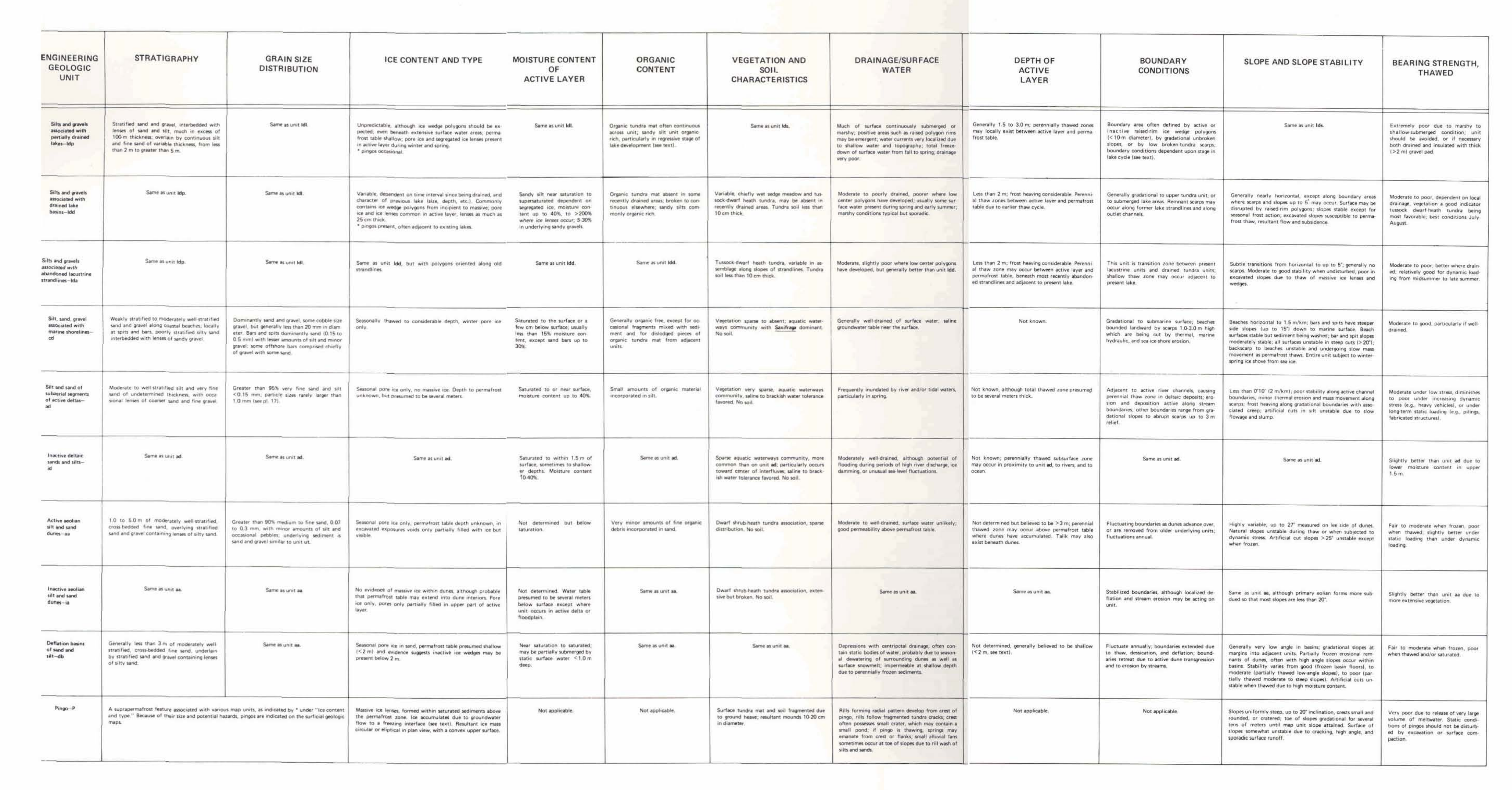




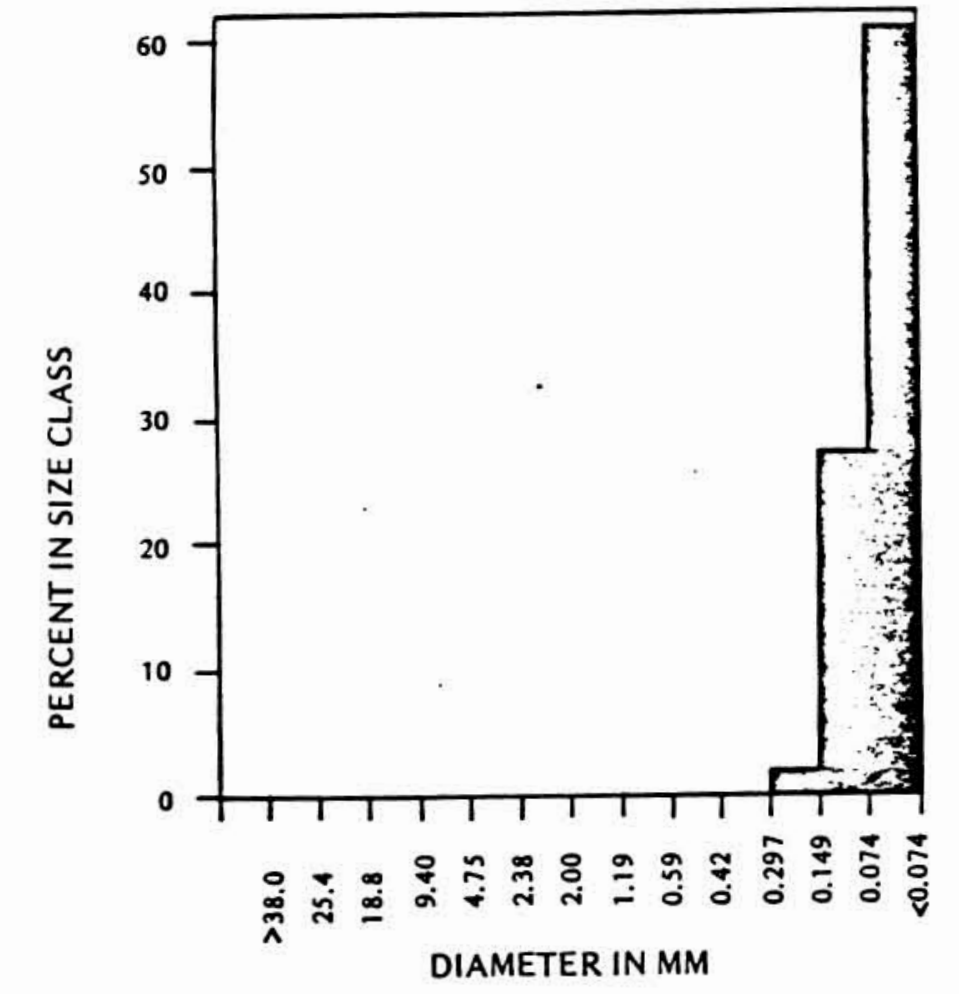

DELTAIC SANDY-SILT SAGAVANIRKTOK RIVER (Unit ad)

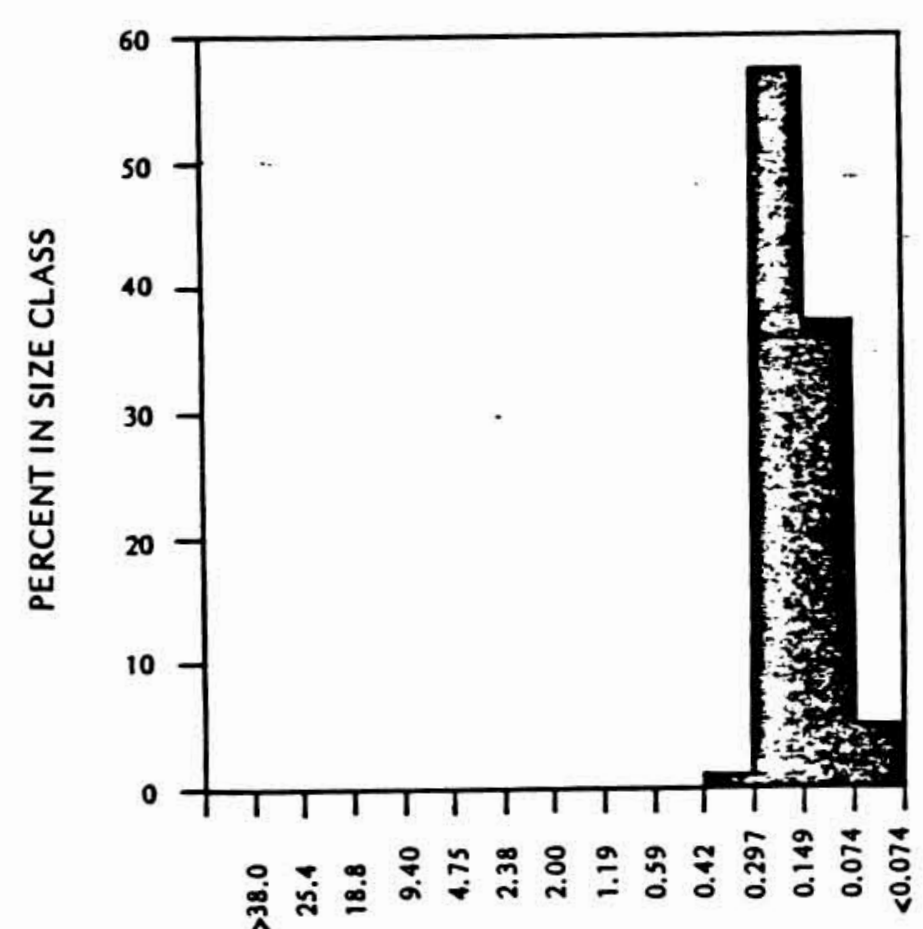

DIAMETER IN MM

SILTY-SAND FROM ACTIVE DUNE (Unit aa)

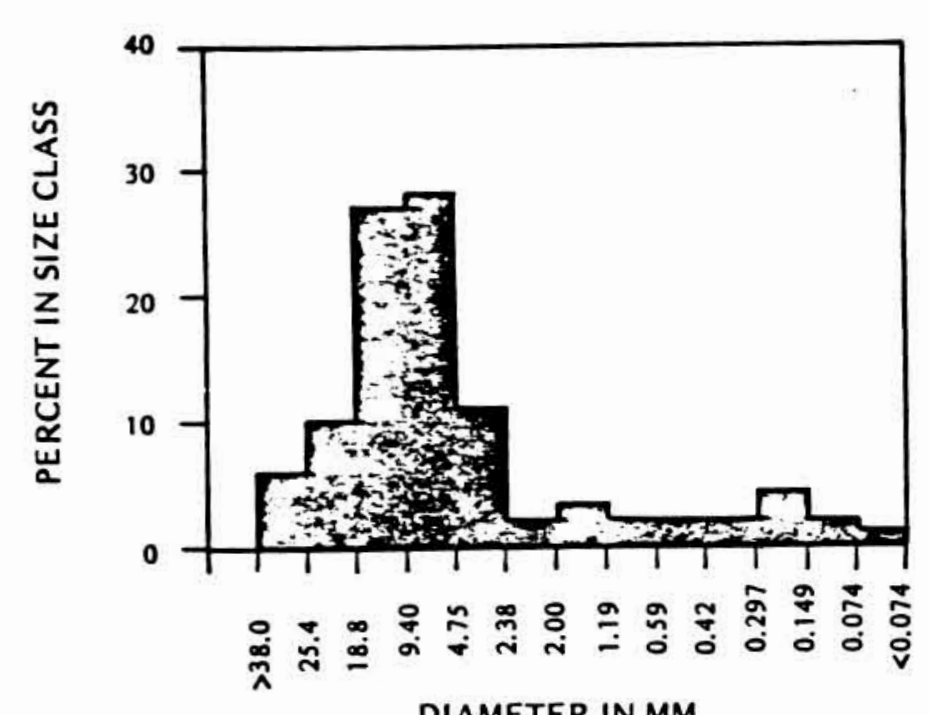

DIAMETER IN MM

SANDY-GRAVEL FROM ACTIVE CHANNEL PUTULIGAYUK RIVER

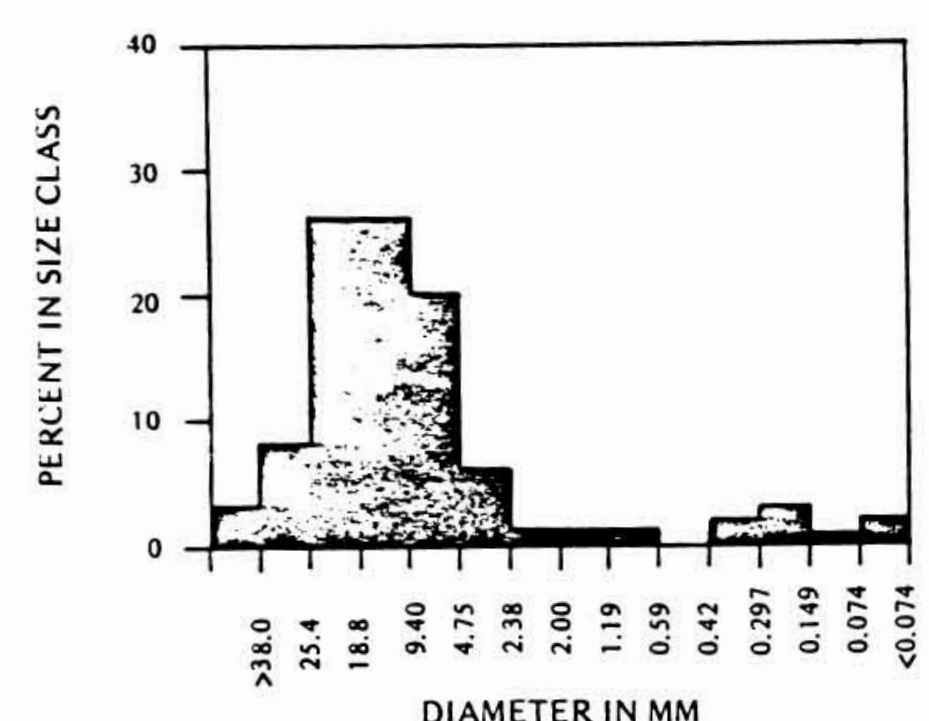

SANDY-GRAVEL FROM ACTIVE CHANNEL SAGAVANIRKTOK RIVER
(Unit af)

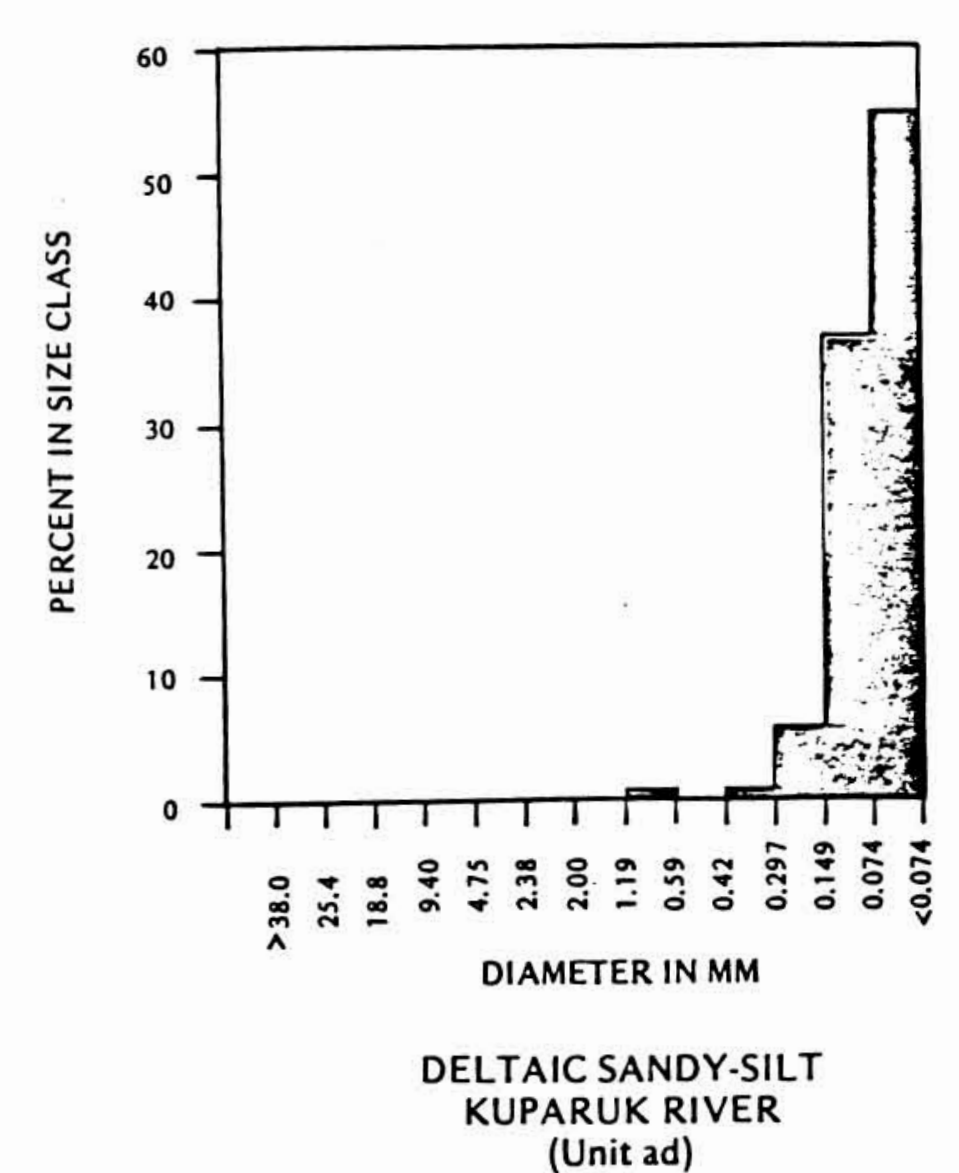

(Unit ad)

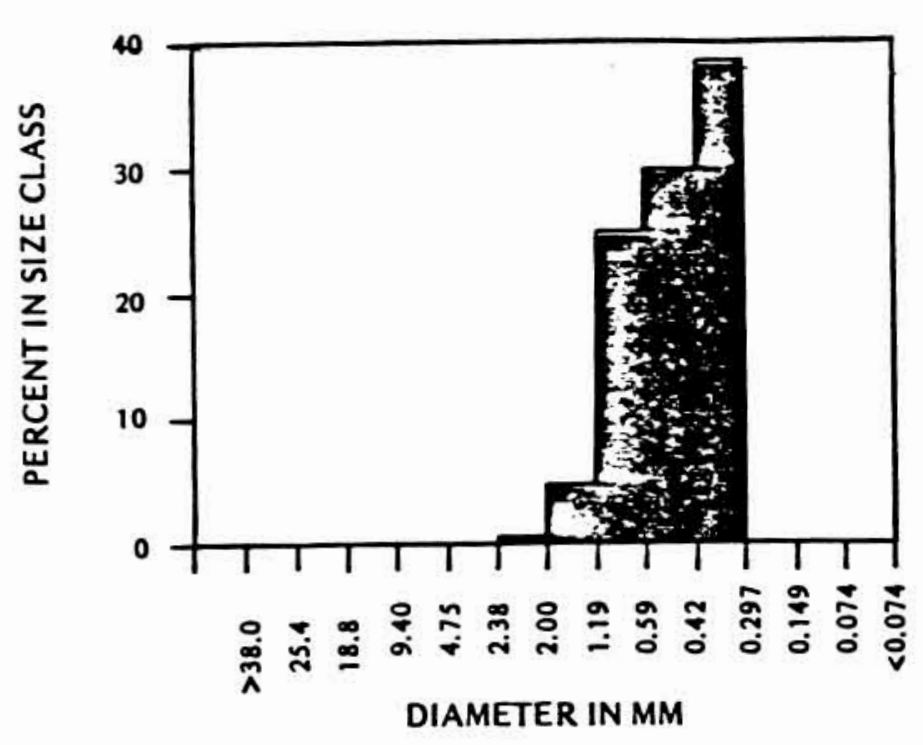

SANDY-SILT COVER ON INACTIVE FLOODPLAIN SAGAVANIRKTOK RIVER (Unit if)

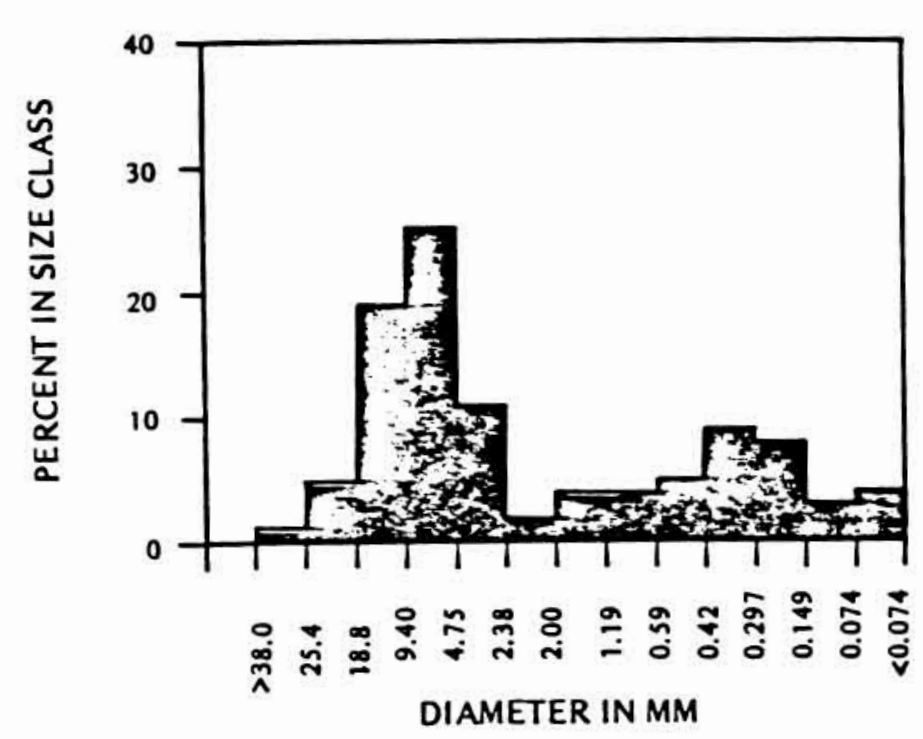

SANDY-GRAVEL FROM INACTIVE FLOODPLAIN AGAVANIRKTOK RIVER (Unit if)

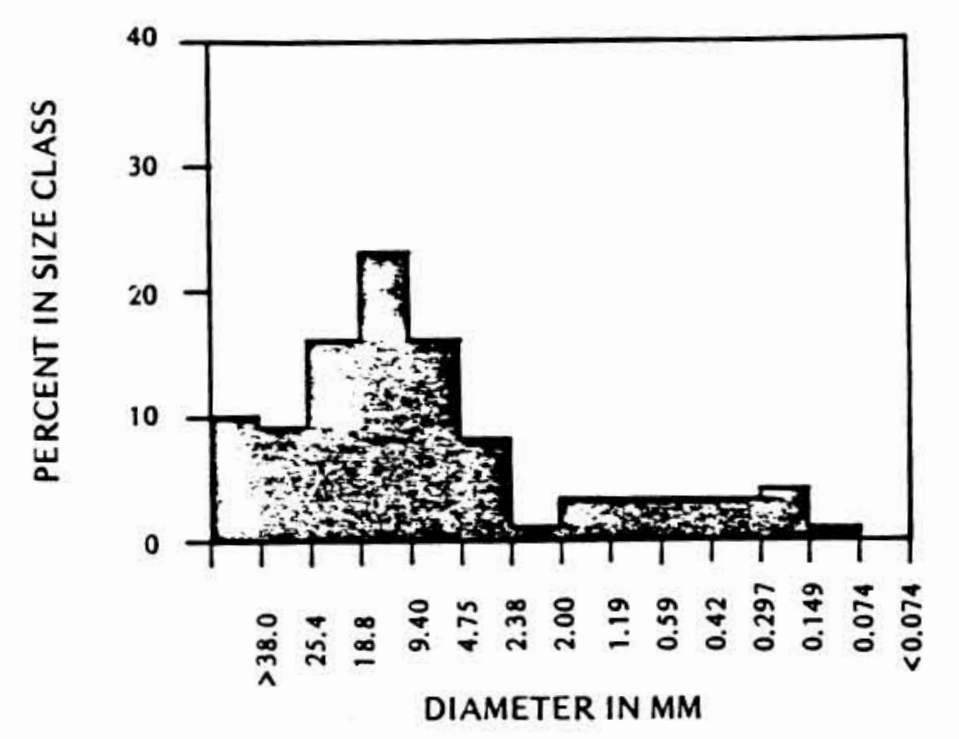

SANDY.GRAVEL FROM ACTIVE CHANNEL (Unit af)
(UPAR RIVER

PLATE 17. HISTOGRAMS SHOWING RELATIVE PARTICLE SIZE DISTRIBUTION OF SEDIMENT SAMPLES REPRESENTATIVE OF SURFICIAL GEOLOGIC MAP UNITS. 